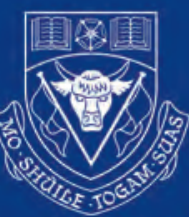

UNIVERSITY OF CALGARY
THE SCHOOL/O PUBLIC PoEtcy

Technical Paper

\title{
THE TIMING AND DIRECTION OF STATUTORY TAX RATE CHANGES BY THE CANADIAN PROVINCES ${ }^{\dagger}$
}

Ergete Ferede, Department of Economics, Grant MacEwan University, Edmonton

Bev Dahlby, The School of Public Policy and Department of Economics, University of Calgary, Calgary

Ebenezer Adjeic, Department of Economics, University of Alberta, Edmonton

\section{SUMMARY}

Tax rate changes are some of the most significant and far-reaching decisions a government can take. A good understanding of the odds of any such changes is essential for any business debating the timing and location of investments. This paper investigates the factors that affect the timing of statutory tax rate changes by Canadian provincial governments. The authors develop a simple theoretical model to explain the "stickiness" of tax rates - the factors that lead a province to decide against tinkering with the tax system - based on the presence of fixed costs of adjusting tax rates. The results indicate that if the current rate falls within a range of tax rates bracketing the optimal rate, then the government will not adjust its tax rate because the cost of the reform outweighs the potential benefits. To build up a body of evidence, this paper employs a multinomial logit model to examine the likelihood of changes to personal income tax (PIT), corporate income tax (CIT), and provincial sales tax (PST) rates by provincial governments over the period 1973-2010. Regression results indicate that provincial governments that start with higher tax rates are more likely to cut, and less likely to raise, their tax rates. A higher provincial budget deficit reduces the probability of a CIT rate cut and raises the probability of a PST rate increase. Party ideology seems to matter. Provinces with leftleaning governments are less likely to cut PIT and PST rates, and more likely to raise PIT rates compared to non-left-leaning governments. The authors also find that a federal PIT rate cut raises the probability of a provincial PIT rate increase, whereas a federal CIT rate cut raises the probability of a provincial $\mathrm{CIT}$ rate reduction.

\footnotetext{
${ }^{\dagger}$ We would like to thank Kenneth McKenzie, Anindya Sen, and participants at the 47th Canadian Economics Association meeting in Montreal and Deloitte Tax Policy Research Symposium in Toronto. All remaining errors are our own.
}

Keywords: optimal taxation; tax reform; tax competition 


\section{INTRODUCTION}

Taxes affect labour supply, saving, investment and a wide range of other private sector economic decisions. The changes in the allocation of resources induced by the tax system can result in large efficiency losses for the economy. Tax-funded public services and infrastructure benefit society when tax revenue is obtained from sources that impose the minimum possible efficiency costs on the private sector. The literature on optimal taxation indicates that this can be achieved - if tax rates are set so that the marginal cost of public funds is equalized across tax bases and are equal to the marginal benefit of government spending financed by the tax revenue.

The implication of this is that governments should adjust tax rates in response to changing economic and fiscal conditions, in order to attain the optimal level and pattern of tax rates. However, frequent tax rate changes are not common in practice. For example, between 1973 and 2010, Canadian provincial governments only changed their personal income tax rates 137 times out of a possible 380 province-year episodes. In other words, 65 per cent of the time, the provinces did not change their personal income tax rates. Corporate income tax rate changes were even less frequent, with only 83 corporate income tax rate changes, and only 52 sales tax rate changes by the provincial governments. Thus, 78 per cent of the time there were no provincial corporate income tax rate changes and 86 per cent of the time there were no sales tax rate changes. Clearly, tax rates are "sticky," a characteristic that does not seem to be consistent with the normative theory of optimal taxation, or with conventional models of tax competition by subnational governments.

Obviously the decision to change tax rates involves a comparison of the gains from adjusting the tax rate with the cost of adjusting the tax rate, including political costs. ${ }^{l}$ Governments are less likely to embark on tax reform when the costs of tax rate changes outweigh the potential gains. What factors tip the balance and make tax rate changes more likely? Is it possible to predict the timing and direction of tax rate changes? We explore these and related important issues in this paper.

There is a paucity of empirical studies that examine the factors that influence the likelihood of tax rate changes in a discrete choice-decision setting. Some of the related studies include Devereux et al for cigarette taxes, ${ }^{2}$ Heinemann et $\mathrm{al}^{3}$ and Hassett and Mathur ${ }^{4}$ for corporate income tax, Foremny and Riedel ${ }^{5}$ for business taxes and Adjei ${ }^{6}$ for personal income tax. ${ }^{7}$ Hassett and Mathur ${ }^{8}$ employ a probit model to analyze the factors that motivate governments to embark on corporate income tax rate cut reforms. Their results suggest that countries that cut the

\footnotetext{
I See for example Hettich, W. and S. Winer. 1988. "Economic and political foundations of tax structure," American Economic Review 9:701-712.

2 Devereux, M., B. Lockwood, and M. Redoano. 2007. "Horizontal and vertical indirect tax competition: theory and some evidence from the USA," Journal of Public Economics 91: 451-79.

3 Heinemann, F., M. Overesch, and J. Rincke. 2010. "Rate cutting tax reforms and corporate tax competition in Europe," Economics and Politics 22: 498-518.

4 Hassett, K. and A. Mathur. 2007. "Predicting tax reform," American Enterprise Institute. Institute for Public Policy Research. Working Paper Number 138.

5 Foremny, D. and N. Riedel. 2012. "Business taxes and the electoral cycle," CESifo Working paper number 3729.

6 Adjei, E. 2012. "Empirical analysis of tax competition among provincial governments in Canada," MA. Thesis. University of Alberta.

7 See Appendix 2 for a more detailed description of the data, statistical techniques and key results in previous studies. The inclusions of federal tax rates of course imply that year-specific effects cannot be included in the model.

8 2007. Op. cit.
} 
corporate income tax rate in the past are more likely to cut the tax rate again. The study also indicates that countries which have a higher corporate income tax rate than their neighbours are more likely to lower their tax rates. In a binary response setting, Heinemann et $\mathrm{al}^{9}$ also investigate the determinants of the likelihood of corporate income tax cuts for European countries. They find that countries are more likely to cut their corporate income tax rates when they have inherited a higher tax rate and neighbours' tax rates are lower. Foremny and Riedel ${ }^{10}$ analyze how political cycles influence business tax rate choices using data from German municipalities.

Our study is most closely related to Adjei, ${ }^{11}$ which uses panel data from Canadian provinces to examine the factors that influence the occurrence and magnitude of personal income tax rate changes. His findings suggest that the occurrence of tax rate changes is affected by the federal personal income tax rate, and that horizontal tax competition influences the magnitude of the tax rate changes. As the focus of $\mathrm{Adjei}^{12}$ is simply on the likelihood of personal income tax rate change, the study does not analyze the factors that affect the likelihood of personal income tax rate cuts and increases separately. One would expect that provincial governments may have asymmetric responses to changes in some of the factors that cause tax rate changes. That is, changes in the fiscal environment can have different effects on the probabilities of tax rate cuts or tax rate increases. Analyzing the likelihood of tax rate cuts and tax rate increases separately, rather than tax rate changes, should provide better insights into governments' fiscal responses.

The main objective of this paper is to examine the factors that influence the likelihood of tax rate cuts and tax rate increases for the personal income tax (PIT), the corporate income tax (CIT), and the general sales tax (PST) imposed by Canadian provincial governments. This study makes two important contributions to the literature. First, we present a simple theoretical model to explain the "stickiness" of tax rates based on the presence of a fixed cost of adjusting tax rates. In this model, the decision to adjust tax rates involves a comparison of the gains from adjusting the tax rate to the optimal tax rate, with the administration and political costs associated with the tax reform. If the government's tax rate falls within a range of tax rates bracketing the optimal tax rate, then the government will not adjust its tax rate, even if it is not the optimal tax rate. The reason for this is that the cost of the tax reform outweighs the potential benefit from the reform.

The second contribution of this paper is that we provide an empirical analysis of the factors that influence governments' tax rate change decisions in a multi-category discrete tax rate choice setting. Previous empirical studies generally frame their analyses as governments having only two choices and employing either logit or probit models. In reality, governments face three distinctive choices about tax rate changes: to lower the tax rate, to raise the tax rate or to keep the tax rate unchanged. Since governments face multiple choices, the appropriate empirical approach needs to take this reality into account. Thus, to address this issue, we employ the multinomial logit regression method in this paper. Using panel data from Canadian provincial governments for the period 1973-2010, our analysis focuses on changes in statutory

\footnotetext{
9 2010. Op. cit.

10 2012. Op. cit.

11 2012. Op. cit.

12 Ibid.
} 
PIT, CIT, and PST rates. To the best of our knowledge, this paper is the first to employ multinomial logit models and frame tax rate reforms as multi-category choice decisions. While the use of such an empirical approach is rare in empirical studies of tax rate changes, it is quite commonly used in studies of occupational choices, ${ }^{13}$ locational choices ${ }^{14}$ and exchange rate regime choices. ${ }^{15}$ Lunderborg and Skedinger ${ }^{16}$ also use such a method to analyze the effects of capital taxation on household mobility.

Our results indicate that a provincial government that starts with a higher tax rate is more likely to cut, and less likely to raise, its tax rate. The empirical results show that a higher provincial budget deficit-to-GDP ratio reduces the probability of a CIT rate cut and raises the probability of a PST rate increase. We also find that provinces with left-leaning governments are less likely to cut and more likely to raise personal income tax rates. They are also less likely to cut the PST rate. Moreover, the results suggest that provincial governments are less likely to raise sales taxes during an election year. Another important finding of our paper is that provincial governments are more likely to cut their PIT and CIT rates when their neighbours lower their rates. We also find that provinces are more likely to increase their PST rates when their neighbours raise their rates. These results are broadly consistent with the horizontal tax competition literature. We also find that a federal PIT rate cut raises the probability of a provincial PIT rate increase, whereas a federal CIT rate cut raises the probability of a provincial CIT rate reduction. A higher provincial PIT rate raises the probability of a provincial CIT rate increase. Finally, an increase in a per-capita grant from the federal government raises the probability of a CIT rate reduction.

The remainder of the paper is organized as follows. In Section 2 we provide a simple theoretical framework to explain how governments adjust their tax rates. Section 3 discusses the empirical methodology and data used in the study. The empirical results are presented and discussed in Section 4. Finally, Section 5 concludes and highlights the policy implications of the paper.

13 See Schmidt, P. and R. Strauss. 1975. "The prediction of occupation using multiple logit models," International Economic Review 16: 471-486; and Harper, B. and M. Haq. 2001. "Ambition, discrimination, and occupational attainment: a study of a British cohort," Oxford Economic Papers 53: 695-720.

14 See Gabriel, S. and S. Rosenthal. 1989. "Household location and race: estimates of a multinomial logit model," Review of Economics and Statistics 71: 240-249; Green, D. 1999. "Immigrant occupational attainment: assimilation and mobility over time," Journal of Labour Economics 17: 49-79; and Abramitzky, R. 2009. "The effect of redistribution on migration: evidence from Israeli Kibbutz," Journal of Public Economics 93: 498-511.

15 Berdiev, A., Kim, Y., C.P. Chang. 2012. "The political economy of exchange rate regimes in developed and developing countries," European Journal of Political Economy 28: 38-53.

${ }^{16}$ Lunderborg, P. and P. Skedinger. 1998. "Capital gains taxation and residential mobility in Sweden," Journal of Public Economics 67: 399-419. 


\section{A SIMPLE MODEL OF TAX RATE ADJUSTMENT}

Suppose a government imposes taxes on a commodity $X$ where the representative consumer's utility function is:

$$
U=\alpha \ln (X)+(1-\alpha) \ln (Z)+b g
$$

where $0<\alpha<1$ is the share of the consumer's income, $M$, that is spent on $X . Z$ represents all of the other untaxed private goods and $g$ is a publicly provided good with a constant marginal utility $b>0$. It is assumed that the producer prices of the three goods, $X, Z$, and $g$ are constant and equal to one. The consumer's budget constraint is:

$$
M=(1+\tau) X+Z
$$

where $\tau$ is the tax rate imposed on consumption of $X$. The tax revenue collected by the government is:

$$
R=\frac{\tau}{1+\tau} \alpha M
$$

All of the government's revenues are spent on the public good $g$. The government's marginal cost of public funds, $\mathrm{MCF}$, is equal to the following:

$$
M C F=\frac{X}{\frac{d R}{d \tau}}=1+\tau
$$

The marginal benefit from the public service is $M B$. Assuming that the cost of producing one unit of the public service is one, the optimal tax expenditure policy would be to set the tax rate such that $M C F=M B$ or in other words to set the tax rate at $\tau_{o}=M B-1$.

Suppose that the government's tax rate is currently set at $\tau \neq \tau_{o}$. In the absence of adjustment costs, the government's optimal policy would be to immediately change the tax rate to $\tau_{o}$. However, suppose there is a fixed cost, $A$, to adjusting the tax rate. This fixed cost might involve printing new tax forms. Perhaps more importantly, there may be a cost of reaching an agreement in the cabinet and Legislature on the need for a tax rate change. The decision to adjust the tax rate will then involve a comparison of the gains from adjusting the tax rate to the optimal tax rate $\tau_{o}$ with the adjustment cost that will be incurred. Figure 1 illustrates the gain, $G$, from adjusting the tax rate when $\tau>\tau_{o}$.

\section{FIGURE 1}

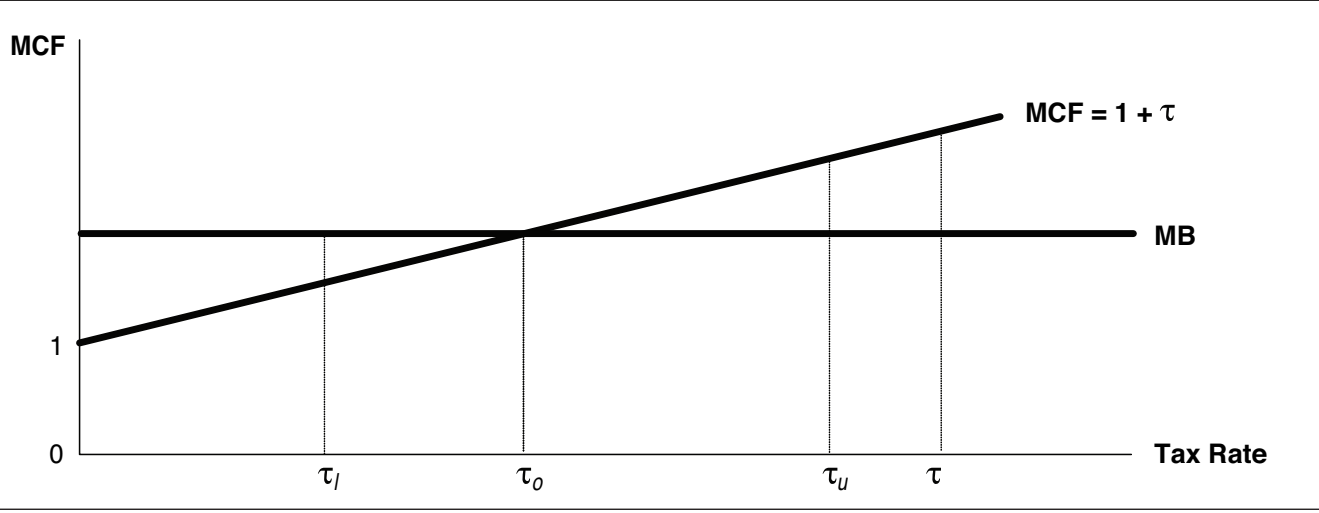


The gain from a small reduction in the tax rate which reduces tax revenues by one dollar is given by the gap between the current $M C F$ and $M B$. As the tax rate is further reduced, the $M C F$ declines and the gain from further reductions in tax revenues and expenditure on $g$ also declines. The total gain from reducing the tax rate from $\tau$ to $\tau_{o}$ can be approximated as:

$$
G=0.5(M B-M C F) \Delta R
$$

where $\Delta R$ is the change in tax revenue when the tax rate changes from $\tau$ to $\tau_{o}$. Suppose that the cost of this once-and-for-all tax rate change is $A$. The present value of the gain from the tax rate change is $G / r$ where $r$ is the discount rate that the government uses to calculate the present value of the gains from policy adjustments. The tax rate adjustment is worthwhile if $r A<G$; otherwise the government should continue with its current tax/expenditure policy.

Since $A$ is a fixed cost and the gain from a tax rate adjustment decreases as the (absolute value) of the tax rate change diminishes, there is a range of tax rates, $\tau_{l}$ to $\tau_{u}$, over which it is not worthwhile to make the tax rate adjustment.

Below we derive the upper and lower bounds for the tax rate departures from the optimal tax rate $\tau_{o} . A$ tax rate adjustment does not yield a net gain if $r A=G$. Using the expressions for the $M C F$ and $R$ in equations (3) and (4), this condition can be written as:

$$
r A=0.5\left(1+\tau_{o}-(1+\tau)\right)\left[\frac{\tau_{o}}{1+\tau_{o}}-\frac{\tau}{1+\tau}\right] \alpha M
$$

Let $\rho=(r A) /(\alpha M)$ be the ratio of the equivalent annual adjustment cost to the expenditure on the taxed commodity. Solving (6) for $\tau$, we obtain the following:

$$
\begin{aligned}
& \tau_{u}=\tau_{o}+\left(\rho+\sqrt{(1+\rho)^{2}-1}\right)\left(1+\tau_{o}\right) \\
& \tau_{l}=\tau_{o}+\left(\rho+\sqrt{(1+\rho)^{2}-1}\right)\left(1+\tau_{o}\right)
\end{aligned}
$$

Therefore the government will reduce its tax rate if $\tau>\tau_{u}$ and increase its tax rate if $\tau<\tau_{l}$. If $\tau_{l}<\tau<\tau_{u}$ the government would not change its current tax/expenditure policy.

As is expected, $\tau_{u}$ is increasing in $\tau_{o}$ and $\rho$ :

$$
\begin{aligned}
& \frac{d \tau_{u}}{d \tau_{o}}=\rho+1-\sqrt{(\rho+1)^{2}-1}>0 \\
& \frac{d \tau_{u}}{d p}=\left(1+\tau_{o}\right)\left[\frac{\rho+1}{\sqrt{(\rho+1)^{2}-1}}+1\right]>0
\end{aligned}
$$

and $\tau_{l}$ is increasing in $\tau_{o}$ and decreasing in $\rho$ :

$$
\begin{aligned}
& \frac{d \tau_{l}}{d \tau_{o}}=\rho+1 \sqrt{(\rho+1)^{2}-1}>0 \\
& \frac{d \tau_{l}}{d p}=\left(1+\tau_{o}\right)\left[1-\frac{\rho+1}{\sqrt{(\rho+1)^{2}-1}}\right]<0
\end{aligned}
$$


In other words, a fiscal event that raises the optimal tax rate will reduce the likelihood of a tax rate reduction and increase the likelihood of a tax rate increase. An increase in the cost of making a tax rate change will increase the likelihood that no tax rate change takes place.

Note that $d \tau_{u} / d \tau_{o}>d \tau_{l} / d \tau_{o}$. This implies that the minimum observed tax rate reduction, $\tau_{u}-\tau_{o}$ will exceed the minimum observed tax rate increase, $\tau_{o}-\tau_{l}$. More generally, we expect asymmetric responses to events that might trigger tax rate increases or decreases.

Figure 2 shows the $\tau_{u}$ and $\tau_{l}$ for $\tau_{o}=0.25$ when $\rho$ varies from 0 to 0.01 .

\section{FIGURE 2}

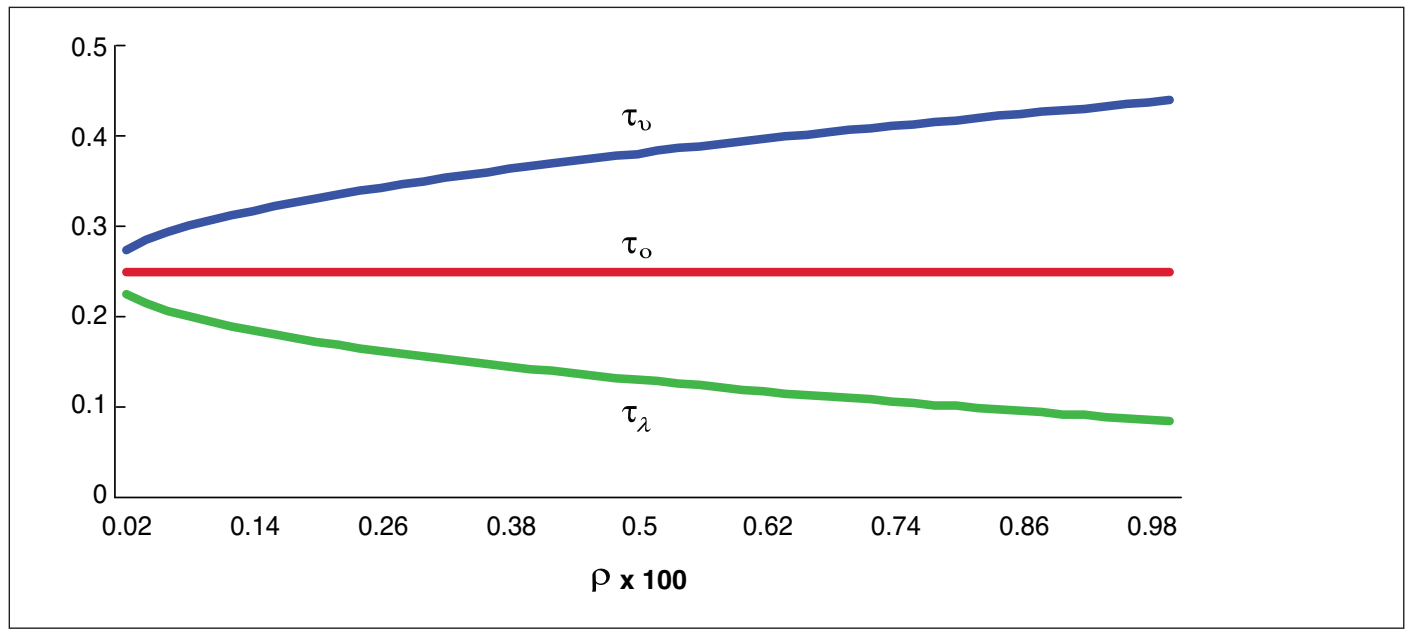

If the annual equivalent adjustment cost is one per cent of the expenditure on the taxed commodity, then no tax change would be observed as long as the tax rate is between 0.085 and 0.44 .

In conclusion, we have developed a simple model that explains the "stickiness" of tax rates based on the presence of a fixed cost of adjusting tax rates. If the government's tax rate falls within a range of tax rates bracketing the optimal tax rate, then the government will not adjust its tax rate, even if its current tax rate is not the optimal tax rate. In the next section, we use this model as the basic framework for investigating tax rate changes by Canadian provincial governments. More specifically, we explore the impacts of various factors that influence the likelihood of tax rate cuts and increases using panel data from the 10 Canadian provinces. 


\section{EMPIRICAL METHODOLOGY AND DATA}

\subsection{Empirical Methodology}

We estimate a multinomial logit model of tax reform in which provincial governments choose to lower, raise or leave tax rates unchanged. That is, in our analysis, the provincial government faces three distinctive choices about tax rates: to lower the tax rate (category, $j=1$ ), to keep the tax rate unchanged (category, $j=2$ ), or to raise the tax rate (category, $j=3$ ). Since the government faces multiple choices, the appropriate econometric method commonly used in the literature is Multinomial Logistic Regression. Basically the method extends the commonly used logit model to accommodate unordered multiple discrete outcomes. ${ }^{17}$ See Wooldridge (2002). The use of such an econometric method is based on the simple model of tax adjustment outlined in Section 2.

Consider provincial government $i$ which faces both the political costs and benefits associated with tax reforms. Let $Y_{i}$ denote a random variable taking on category values $J=1,2,3$, where $Y=1$ when $\Delta \tau<0$ and the government reduces its tax rate, $Y=2$ when $\Delta \tau=0$ and it leaves its tax rate unchanged, and $Y=3$ when $\Delta \tau>0$ and it increases its tax rate. The probability (Pr) of choosing category $j$ is such that:

$$
\begin{aligned}
& \operatorname{Pr}\left(Y_{i}=1\right)=\operatorname{Pr}\left(\tau>\tau_{u}\right) \\
& \operatorname{Pr}\left(Y_{i}=3\right)=\operatorname{Pr}\left(\tau<\tau_{l}\right) \\
& \operatorname{Pr}\left(\mathrm{Yi}_{\mathrm{i}}=2\right)=1-\left(\operatorname{Pr}\left(Y_{i}=1\right)+\operatorname{Pr}\left(Y_{i}=3\right)\right)
\end{aligned}
$$

Eq. (11c) captures the probability that the government would not change its tax rate and corresponds to the "sticky" tax rate region implied in the simple model.

We assume that the critical tax rates, $\tau_{u}$ and $\tau_{l}$ can be written as:

$$
\begin{aligned}
\tau_{u i} & =\beta_{11} x_{1 i}+\beta_{12} x_{2 i}+\cdots+\beta_{1 \mathrm{n}} x_{n i}+\varepsilon_{1 i} \\
\tau_{l i} & =\beta_{31} x_{1 i}+\beta_{32} x_{2 i}+\cdots+\beta_{3 \mathrm{n}} x_{n i}+\varepsilon_{3 i}
\end{aligned}
$$

where $x_{j i}$ denotes a vector of explanatory variables that affect either the optimal tax rate, $\tau_{o}$, or the cost of tax reform, $\rho$, and $\varepsilon j i$ is the error term. Thus, for the three major taxes: personal income, corporate income, and sales tax rates, the empirical model can be specified as:

$$
\mathrm{Y}^{*}{ }_{i j t}=x_{i j t}{ }^{\prime} \beta+\varepsilon_{i j t}
$$

Under the assumption that the error term, $\varepsilon_{j i}$, in Eq. (13) follows a logistic distribution, the multinomial logit model has response probabilities $(P r)$ for the choice of tax rate cut $(j=1)$ and tax rate increase $(j=3)$ given by

$$
\operatorname{Pr}\left(Y_{i}=j \mid x_{i}\right)=\frac{\exp \left(\beta_{j}{ }^{\prime} x_{i}\right)}{1+\sum_{\mathrm{k}=1}^{\mathrm{j}} \exp \left(\beta_{k}{ }^{\prime} x_{i}\right)} \quad j=1,3
$$

\footnotetext{
17 Greene, W. 2008. Econometric Analysis, 6th edition, Prentice Hall.
} 
We use the tax reform category of no tax rate change $(j=2)$ as a reference category. Since probabilities sum to one, the probability for our reference category $j=2$ is given by

$$
\operatorname{Pr}\left(Y_{i}=2 \mid x_{i}\right)=\frac{1}{1+\sum_{\mathrm{k}=1}^{\mathrm{j}} \exp \left(\beta_{k}{ }^{\prime} x_{i}\right)}
$$

The multinomial logit model provides the log-odds ratio associated with the choices of tax reform category lower tax rate $(j=1)$ and raise tax rate $(j=3)$ as

$\ln \left[\frac{P r_{i 1}}{P r_{i 2}}\right]=x_{i}{ }^{\prime} \beta_{1}$ and $\ln \left[\frac{P r_{i 3}}{P r_{i 2}}\right]=x_{i}{ }^{\prime} \beta_{3}$, respectively.

Thus we have basically two equations: tax rate-cut and tax rate- increase equations. ${ }^{18}$

In Eq. (13), the effects of the various control variables $\left(x_{i j t}\right)$ on the tax rate change categories $\left(Y^{*}{ }_{i j t}\right)$ reflect the impacts of various factors on the optimal tax rate. Thus it is directly related to the simple model we discussed previously. Figure 3 shows the probability distribution functions for $\tau u$ and $\tau_{l}$ for given values of the $x_{i j t}$. Given that the government's current tax rate is $\tau^{\prime}$, the probability of a tax rate reduction is the shaded area in the left-hand tail of the distribution for $\tau_{u}$ in Panel A, and the probability of a tax rate increase is the shaded area in the right-hand tail of the distribution for $\tau_{l}$ in Panel B. The model outlined in Section 2 indicates that changes in the optimal tax rate, $\tau_{o}$, or changes in the cost of adjustment, $\rho$, will affect the probability of a tax rate reduction or a tax rate increase. Intuitively, those variables that increase $\tau_{o}$ will shift the probability density functions (pdfs) for $\tau_{u}$ and $\tau_{l}$ to the right, which will reduce the probability of a tax reduction and increase the probability of a tax rate increase. Alternatively, any variable that increases $\rho$ will shift the pdf for $\tau_{u}$ to the right and shift the pdf for $\tau_{l}$ to the left, thereby reducing both the probability of a tax rate reduction and a tax rate increase. The empirical model shown in Eq. (13) should be interpreted in terms of the variables that affect the optimal tax rate and affect the cost of adjusting the tax rate.

FIGURE 3

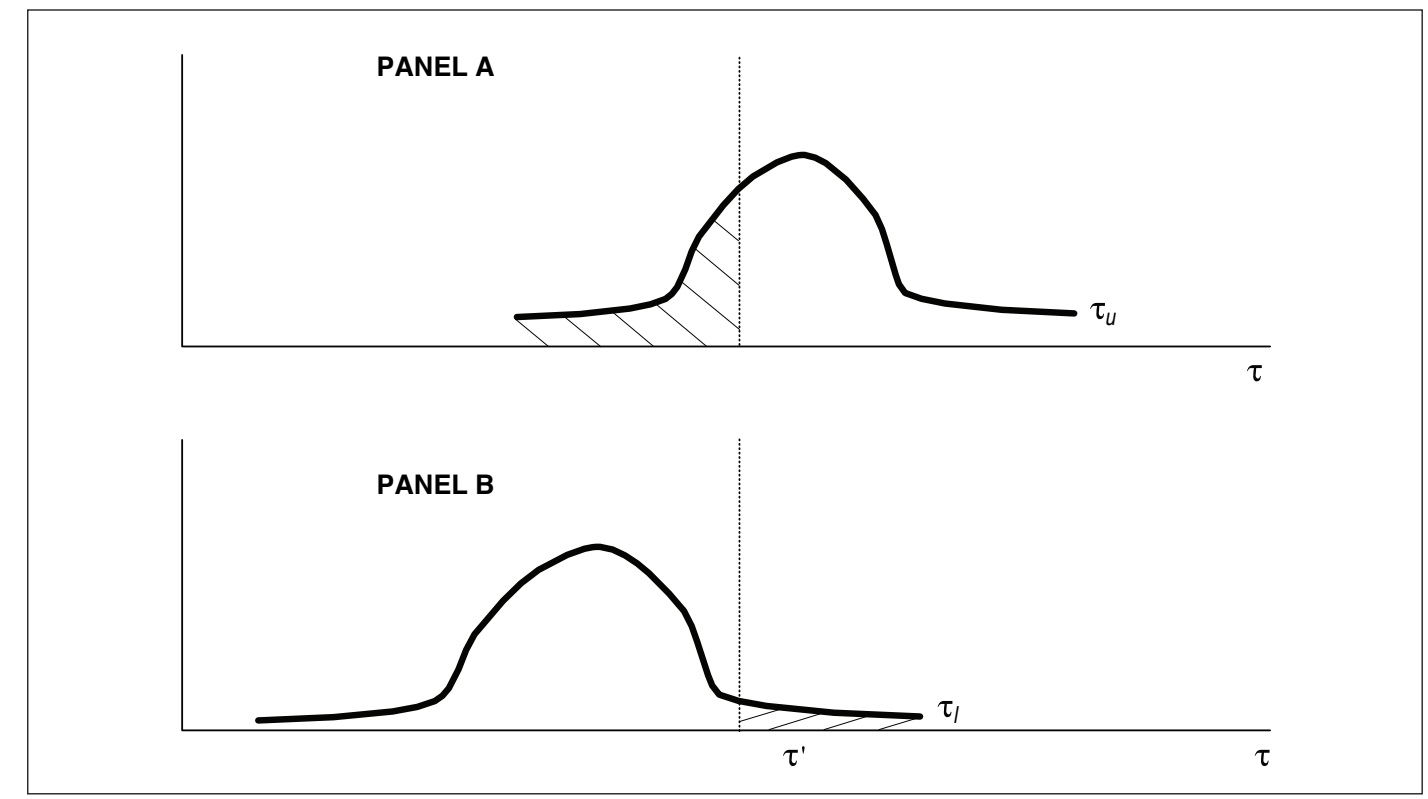

${ }^{18}$ See Agresti, Alan. 2007. An introduction to categorical data analysis. John and Wiley and sons. Second Edition. New Jersey; and Greene 2008. Op. cit. 
In our analysis, we control for various fiscal and political variables that are likely to influence the province's optimal tax rate and the cost of adjusting taxes. Table 1 lists the variables that we have included in the logistic regressions to capture changes in $\tau$, and those that affect $\rho$ as well as the hypothesized effects of these variables on $\tau_{o}$ and $\rho$. The rationale for including each of these variables is given below.

\section{TABLE 1: THE DETERMINANTS OF THE LIKELIHOOD OF A TAX RATE CHANGE}

\begin{tabular}{|c|c|}
\hline Variables Affecting the Optimal Tax Rate $\tau_{o}$ & Variables Affecting the Cost of Tax Changes $\rho$ \\
\hline $\begin{array}{l}\text { A Province's Fiscal Variables: } \\
\text { · The provincial government's deficit (+) } \\
\text { · A simultaneous increase in the province's other tax rates (?) } \\
\text { - A simultaneous decrease in the province's other tax rates (?) } \\
\text { Federal Tax Policy: } \\
\text { - A reduction in the federal tax rate (?) } \\
\text { · Per-capita grants from the federal government (-) } \\
\text { Other Provinces' Tax Policies: } \\
\text { - Other provinces' tax rates (+) } \\
\text { - A cut in other provinces' tax rates (-) } \\
\text { - An increase in other provinces' tax rates (+) } \\
\text { Political Environment: } \\
\text { Left-leaning government }(+)\end{array}$ & $\begin{array}{l}\text { Political Environment: } \\
\text { - An election in the current year }(+) \\
\text { - An election in the following year }(+)\end{array}$ \\
\hline
\end{tabular}

Arguably, one of the most important factors that affects a government's decision to embark on tax reform is its fiscal position. When governments continuously run budget deficits, they will be motivated to raise taxes or cut spending or both. Budget surpluses will have the opposite effects. Thus, as in Hayashi and Boadway, ${ }^{19}$ we control for these effects by including the lagged provincial government's budget deficit-to-GDP ratio ( Deficit $_{t-1}$ ). A higher budget deficit-to-GDP ratio is expected to raise the likelihood of tax rate increases and reduce the likelihood of tax rate cuts. Thus we expect the coefficient of the budget deficit-to-GDP ratio to be positive in the tax rate increase equation. We also expect the coefficient of this variable to be negative in the tax rate-cut equation. This is because a higher budget deficit-to-GDP ratio makes tax rate-cut reforms less likely, due to the implication of tax rate cuts on government tax revenues, which are needed to finance the various public services.

The Canadian federal government provides grants to all provinces that allow them to provide higher levels of public services at lower provincial tax rates. In our analysis, we control for this effect by including real federal grants per capita (Grant) as an exogenous variable. When provincial governments receive higher federal grants per capita, they may raise their spending on public services or lower their tax rates or both. Thus, other things remaining the same, we expect that higher federal grants per capita to reduce the probability of tax rate increases and raise the probability of tax rate cuts. That is, we expect the coefficient of federal grants per capita to be positive and negative in the tax rate-cut and tax rate-increase equations, respectively.

19 Hayashi, M.,and R. Boadway. 2001. "An empirical analysis of intergovernmental tax interaction: the case of business income taxes in Canada," Canadian Journal of Economics 34: 481-503. 
Tax policy choices are likely to be influenced by the ideological orientation of the governing political party. As discussed widely in the literature, left-leaning governments generally have a tendency to be pro-tax increase. ${ }^{20}$ In our analysis, we attempt to capture the political dimension of tax reform by including a dummy variable for the left-leaning parties. As in Kneebone and McKenzie, ${ }^{21}$ we include a dummy variable (Left) that is equal to one if the Premier of the province belongs to the Liberal Party or the New Democratic Party (NDP) - the center-left political parties in Canada. If left-leaning governments tend to be pro-tax increase, we expect the coefficient of this variable to be negative and positive in the tax rate-cut and tax rateincrease equations, respectively.

Governments naturally look at their political positions when they contemplate tax reforms. Consequently, the timing of tax rate changes may well depend on whether the government is facing an election. Politicians may time the tax reform in order to maximize their chances of getting re-elected. As Ashworth and Heyndels ${ }^{22}$ argue, politicians' opinions about the levels of tax rates are driven by their belief about the political costs associated with the tax rates. Our simple theoretical model also suggests that governments compare such costs of a reform with any benefit of tax rate changes in their decision to change tax rates or not. To control for this political cycle's effects on the likelihood of tax reform, we include dummy variables for the election year and the year after the election. The dummy variables are equal to one if there is an election in the current year $\left(\right.$ Election $\left._{t}\right)$ or next year $\left(\right.$ Election $\left._{t+1}\right)$. We expect that provincial governments embark on popular tax reforms during election years and postpone unpopular ones for years after an election. Other things remaining the same, we expect the probability of tax rate increases to be lower and tax rate cuts to be higher if the provincial government faces an election in the current or next year. That is, we expect the coefficient of Election ${ }_{t}$ and Election $_{t+1}$ to be positive and negative in the tax rate-cut and tax rate-increase regressions, respectively. The reason is that, as noted in the previous section, when the cost of tax reform is higher, as is the case around election times, the government is less inclined to raise tax rates and more motivated to cut tax rates.

When governments introduce tax reforms they sometimes change more than one tax rate. Thus we need to control for the interrelationship between the various major taxes. This is particularly true for corporate income and personal income tax rates. One basic argument for the presence of corporate income tax rates is that they can serve as a backstop for personal income tax rates. When governments change one of the tax rates, they may well also change the other rate to maintain the integrity of the income tax structure. To account for this, in the PIT and CIT equations we include two dummy variables that are equal to one if the province cuts or raises the other tax rate. The variables enter the regression contemporaneously to account for the possible multiple tax rate changes.

\footnotetext{
${ }^{20}$ See for example Reed, R. W. 2006. "Democrats, Republicans, and Taxes: Evidence Political Parties Matter," Journal of Public Economics 90: 725-50.

21 Kneebone, R. and K. McKenzie. 2001. "Electoral and Partisan Cycles in Fiscal Policy: An Examination of Canadian Provinces," International Tax and Public Finance 8: 753-774.

22 Ashworth, J. and B. Heyndels. 1997. "Politicians' preferences on local tax rates: An empirical analysis," European Journal of Political Economy 13: 479-502.
} 
The vertical tax externality literature has emphasized the interdependence of provincial and federal tax bases when both levels of government co-occupy the same tax base..$^{23}$ Thus the federal tax rate may influence the likelihood of tax rate changes by the provincial government. We control for this effect by including the statutory federal corporate income tax rate in the CIT equations and top personal income tax rates in the PIT equations. ${ }^{24}$ As the federal goods and services tax (GST) remained constant for most of the period under consideration, we do not include the GST in our provincial sales tax equations.

The literature on horizontal tax competition suggests that, due to the mobile nature of tax bases, tax rates in other provinces can have a positive effect on a province's tax base. That is, when other provinces raise their tax rates, the tax base shifts from the higher-tax jurisdiction to a lower-tax jurisdiction (see for example Hayashi and Boadway, ${ }^{25}$ Esteller-Morè and SolèOllè, ${ }^{26}$ Mintz and Smart, ${ }^{27}$ Karkalakos and Kotsogiannis, ${ }^{28}$ Devereux, et al.$^{29}$ and Dahlby and Ferede.) $)^{30}$ Thus changes in neighbours' tax rates can motivate provinces to change their own tax rates. Arguably personal and corporate income tax bases are more mobile than sales tax rates. Consequently, we expect that provinces are likely to be influenced not only by the actions of their immediate geographic neighbours, but also by other provinces in the federation. Thus, for corporate and personal income tax rates, the "neighbours' tax rate" is the weighted average (weighted by the inverse of the distance between major population centres of provinces) tax rate of all other provinces. ${ }^{3 l}$ For sales taxes, on the other hand, we use immediate geographical proximity to define neighbourliness as commonly used in the literature.

Thus, to account for the effects of horizontal tax competition, we include three variables as control variables. The first one is the weighted average tax rate of other provinces. This captures the level effects of other provinces' tax rates. This variable is one period-lagged in order to avoid the problem of endogeneity. We also account for neighbouring provinces' tax rate changes by including two dummy variables: a dummy variable that is equal to one if the neighbours cut their tax rates and another one if they increase their rates. If the usual horizontal competition hypothesis holds, we expect the coefficients of lagged tax rates of other provinces to be negative in the tax rate-cut equation and positive in the tax rate-increase equation, respectively. This is because when other provinces have a lower tax rate, this would motivate

23 See Dahlby, B. and S. Wilson. 2003. "Vertical fiscal externalities in a federation," Journal of Public Economics 87: 917-930.

24 The inclusions of federal tax rates of course imply that year-specific effects cannot be included in the model.

25 2001. Op. cit.

${ }^{26}$ Esteller-Morè, A., and A. Solè-Ollè. 2002. "Tax setting in a federal system: the case of personal income taxation in Canada," International Tax and Public Finance 9: 235-57.

27 Mintz, J., and M. Smart. 2004. "Income shifting, investment and tax competition: theory and evidence from provincial taxation in Canada," Journal of Public Economics 88: 1149-1168.

${ }^{28}$ Karkalakos S., and C. Kotsogiannis. 2007. "A spatial analysis of provincial corporate income tax responses: evidence from Canada," Canadian Journal of Economics 40 (3): 782- 81124

29 2007. Op. cit.

30 Dahlby, B. and E. Ferede. 2012. "The Effects of Tax Rate Changes on Tax Bases and the Marginal Cost of Public Funds for Provincial Governments," International Tax and Public Finance 19:844-883.

31 See Hayashi and Boadway 2001. Op. cit. 
provinces to lower their own rates or discourage them from raising their tax rates. A province is more likely to cut or raise its tax rates when its neighbours cut or raise their tax rates, respectively. Thus we expect the coefficient of the dummy variable for a tax rate cut by neighbours to be positive in the tax rate-cut equation and negative in the tax rate-increase equations. Similarly, we expect the coefficient of the dummy variable for a tax rate increase by neighbours to be negative in the tax rate-cut equations and positive in the tax rate-increase equations.

In addition to these variables, the province's own lagged tax rate is likely to have an impact on the likelihood of a tax rate change. As noted above, a provincial government that inherits a higher tax rate is more likely to lower its rates and less likely to raise its tax rate. To account for this, we include the province's own tax rate in the previous period as an explanatory variable. We expect the coefficient of this variable to be positive in the tax rate-cut equation and negative in the tax rate-increase equation.

While the signs and statistical significance of the multinomial logistic regression coefficient estimates provide important insights about the impacts of various factors on the likelihood of tax rate cuts or increases, the numerical magnitudes of the coefficient estimates do not have straightforward interpretations. Thus, we attempt to explain the importance of the numerical magnitude for the coefficient estimates by computing the corresponding odds ratios. The odds ratios are obtained by simply exponentiating the reported multinomial logit estimates. Odds ratio estimates are non-negative and values greater (less) than one imply that a tax rate change is more (less) likely to occur relative to the reference category.

\subsection{Data}

Our empirical specification is estimated using annual aggregate panel data from the 10 Canadian provinces for the period 1973-2010. The data for our empirical analysis come from various sources. The data on statutory top personal income tax rates (PIT), corporate income tax rates (CIT), and sales tax rates (PST) were obtained from various issues of Finances of the Nation (formerly National Finances) published by the Canadian Tax Foundation. Annual budget balance, population, and federal grants data come from the Statistics Canada database (CANSIM). The information on governing political parties is from the Canadian Parliamentary Guide. Appendix 1 provides details on the definitions and sources of data for the various variables.

As noted before, our analysis focuses on provincial personal income tax, corporate income tax and sales taxes. Some of the previous studies such as Hayashi and Boadway ${ }^{32}$ use effective rather than statutory tax rates in their analysis. However, it is well known that, due to the way they are often computed, effective tax rates can change even though the government does not change its tax policies. That is, changes in effective tax rates may be due to changes in government tax policies or due to changes in other economic variables on which the computations of the effective rates are based. Thus we believe that statutory tax rates are the appropriate variable to use in tax policy studies such as ours.

32 2001. Op. cit. 
The statutory marginal PIT rate generally varies from one income bracket to another. Ideally we would prefer to construct an average PIT rate using the number of individuals in each income bracket as a weighting factor. However, such data are unavailable. Consequently, as in Dahlby and Ferede, ${ }^{33}$ we use the statutory top PIT rate, including all applicable surtaxes as our personal income tax rate. We believe that focusing on just the top statutory PIT rate would capture most of the tax rate changes by provincial governments. The PIT rate also includes all applicable surtaxes. The CIT rate is also the statutory general corporate income tax rate.

Similarly for the sales tax rate, we use the provincial statutory sales tax rate. For those provinces which harmonized their sales tax rates with the GST, we consider that there is a sales tax rate change only when the province adjusts its rate regardless of what happens to the GST.

\section{TABLE 2: N NUMBER OF TIMES THAT GOVERNMENTS CHANGED TAX RATES, 1973-2010}

\begin{tabular}{|l|rrr|rrr|rrr|}
\hline \multirow{2}{*}{ Province } & \multicolumn{3}{|c|}{ Tax rate cuts } & \multicolumn{3}{c|}{ Tax rate increases } & \multicolumn{3}{c|}{ No tax rate changes } \\
\cline { 2 - 9 } Newfoundland & CIT & PIT & PST & CIT & PIT & PST & CIT & PIT & PST \\
PEI & 2 & 4 & 1 & 5 & 12 & 4 & 31 & 22 & 33 \\
Nova Scotia & 0 & 2 & 2 & 2 & 9 & 3 & 36 & 27 & 33 \\
New Brunswick & 0 & 5 & 2 & 4 & 6 & 4 & 34 & 27 & 32 \\
Quebec & 5 & 10 & 2 & 6 & 8 & 3 & 27 & 20 & 33 \\
Ontario & 3 & 7 & 4 & 10 & 2 & 2 & 25 & 29 & 32 \\
Manitoba & 2 & 6 & 1 & 5 & 14 & 3 & 31 & 18 & 34 \\
Saskatchewan & 7 & 6 & 1 & 3 & 3 & 3 & 28 & 29 & 34 \\
Alberta & 5 & 10 & 4 & 5 & 4 & 5 & 28 & 24 & 29 \\
British Columbia & 5 & 6 & 0 & 3 & 3 & 0 & 30 & 29 & 38 \\
All provinces & 6 & 9 & 4 & 5 & 11 & 4 & 27 & 18 & 30 \\
& $\mathbf{3 5}$ & $\mathbf{6 5}$ & $\mathbf{2 1}$ & $\mathbf{4 8}$ & $\mathbf{7 2}$ & $\mathbf{3 1}$ & $\mathbf{2 9 7}$ & $\mathbf{2 4 3}$ & $\mathbf{3 2 8}$ \\
\hline
\end{tabular}

Table 2 provides some descriptive information on provincial tax rate-change choices for the three major taxes. During the period under consideration, there were 137 personal income tax rates changes, 83 corporate income tax rate changes, and only 52 sales tax rate changes by the provincial governments. Most of the instances of tax rates cuts and increases occur in personal income taxes. There were 65 PIT rate cuts and 72 PIT rate increases over the period 1973$2010 .{ }^{34}$ Note that as the PIT includes applicable surtaxes, PIT rate changes can occur when there is a change in the statutory PIT rate or when there is a change in a surtax. The number of PIT rate cuts range from two in Prince Edward Island to 10 in New Brunswick and Saskatchewan. The number of PIT rate increases varies from two in Quebec to 14 in Ontario. Corporate income tax rate cuts are also more common in western Canada than Atlantic Canada. While Prince Edward Island and Nova Scotia did not cut the CIT rate during the period, British Columbia and Manitoba cut their CIT rates six and seven times, respectively. The number of CIT rate increases also range from two in Prince Edward Island to 10 in Quebec. All Canadian

\footnotetext{
33 2012. Op. cit.

34 Prior to 2001, provincial personal income tax rates (with the exception of Quebec) were expressed as a percentage of the federal PIT rate. In such cases, provincial tax rate changes can occur when either the provincial government, or the federal government or both change their respective PIT rates. As our interest is to analyze the factors that affect provincial tax rate changes, we only consider a provincial PIT rate change to have occurred if the provincial government changed its PIT rate, regardless of what happened to the federal PIT rate.
} 
provinces with the exception of Alberta impose sales taxes. Thus in Table 2, sales tax rate cuts and increases are zero for Alberta. As Table 2 shows, sales tax rate changes are less common than CIT and PIT changes. While Newfoundland, Ontario, and Manitoba cut their sales tax rates only once, Quebec, Saskatchewan, and British Columbia each cut their sales tax rates four times. The number of PST increases also ranges from two in Quebec to five in Saskatchewan.

Although the focus of our study is on the direction of tax rate adjustment, the magnitude of tax rate changes is of interest. Since our PIT rate includes surtaxes, there is a lot of variation in the magnitude of PIT rate changes. PIT rate cuts range from four-thousandths of a percentage point (in British Columbia in 1998) to almost seven percentage points (in Saskatchewan in 1977). PIT rate increases also range between four-thousandths of a percentage point (in British Columbia in 1997) to about seven percentage points (in Nova Scotia in 1995). The very small changes in PIT rate observed in British Columbia are due to small changes in the applicable surtaxes. ${ }^{35}$ Provincial corporate income tax rate cuts also range from 0.14 of a percentage point in 2003 to five percentage points in 1982 in Quebec. Similarly corporate income tax rate increases range from 0.13 of a percentage point (in Quebec in 1987) to five percentage points (in Prince Edward Island in 1987). Provincial sales tax rate cuts range from 0.07 of a percentage point (in Quebec in 2006) to four percentage points in Newfoundland in 1998. Sales tax rate increases also range between 0.3 of a percentage point in New Brunswick to three percentage points in British Columbia in 1982.

\section{EMPIRICAL RESULTS AND DISCUSSIONS}

Tables 3-5 present the multinomial logit regression estimates for the probability of tax rate cuts and increases for the three major provincial taxes: PIT, CIT, and PST. As the state of no tax rate change is the reference category, the estimated coefficients reflect the effects of the various covariates on the probability of lowering or raising the tax rate relative to the choice of leaving the tax rate unchanged. In all cases, columns (1) and (2) show the estimated results for the probability of lowering and raising the corresponding tax rate, respectively. While we control for various fiscal and political variables in columns (1) and (2), we include demographic covariates in columns (3) and (4), but the coefficient estimates of these variables are not reported for the sake of brevity. We report standard errors that are robust to heteroskedasticity. In all regressions, we include province-specific fixed effects. Note, however, that due to the presence of federal fiscal variables and other dummy variables that change only over time, we do not include year-specific effects in our analysis.

35 Our analysis, however, shows that the results are not sensitive to the exclusion of these very small changes in the PIT rate. 
We first focus on the discussion of regression results shown in columns (1) and (2) of Tables 35 . The estimated regression models generally perform well as measured by the percentage of correct predictions, the pseudo R-squared, and the log-likelihood ratios. We also present the average probabilities of tax cuts and tax increases predicted by the model over the period 1973 to 2010 in Table 6 . These probabilities are computed based on regression results shown in columns (1) and (2) of Tables 3-5. Table 6 shows that Quebec has the highest predicted probability of a CIT rate increase and the lowest predicted probability of a PIT rate increase, whereas Ontario had the highest predicted probability of a PIT rate increase. Note that because it does not levy a provincial sales tax, the predicted probabilities of a sales tax rate increase or decrease for Alberta are zero.

In order to provide a more intuitive interpretation of the regression results and to assess their economic as well as statistical significance, we have calculated the changes in the probabilities of a tax cut or a tax increase from the estimated coefficients in Tables 3-5 when an exogenous variable changes. We focus our discussion on these changes in probabilities rather than the reported log-odds ratio estimates as the former are more appealing and intuitive. As shown in Appendix 4, the changes in probabilities of tax rate changes depend not only on the estimated coefficients in the tax cut and tax increase equations, but also on the initial or baseline probabilities. Since these can vary by province, we use the average probabilities of tax cuts and tax increases predicted by the model over the entire 1973-2010 period for Alberta and Ontario, to illustrate how the changes in the probabilities vary by province. One can conduct similar analysis for the other provinces.

\subsection{A Province's Fiscal Variables}

In this section we discuss the estimated effects of the fiscal variables identified in Table 1 on the likelihood of a tax change. As indicated in Figures 2 and 3, the likelihood of a tax change depends on the tax rates that the government inherits. The coefficients of lagged tax rates $\left(P I T_{t-1}, C I T_{t-1}\right.$, and $\left.P S T_{t-1}\right)$ are, as expected, positive in the tax cut equations (column (1)) and negative in the tax increase equations (column (2)). The results indicate that for the tax rate-cut equation, the lagged tax rate is statistically significant in the cases of PIT and PST. For the tax rate-increase equation, it is significant only for CIT and PST. The implication of this is that while provinces that inherit higher PIT and PST rates are more likely to cut their tax rates, provinces that inherit higher CIT and PST rates are less likely to raise their tax rates. 
TABLE 3: $\quad$ MULTINOMIAL LOGIT ESTIMATES FOR PIT RATE CHANGES, 1973-2010

\begin{tabular}{|c|c|c|c|c|}
\hline & $\begin{array}{l}\text { Lower PIT rate } \\
\text { (1) }\end{array}$ & $\begin{array}{l}\text { Raise PIT rate } \\
\text { (2) }\end{array}$ & $\begin{array}{l}\text { Lower PIT rate } \\
\text { (3) }\end{array}$ & $\begin{array}{c}\text { Raise PIT rate } \\
\text { (4) }\end{array}$ \\
\hline $\mathrm{PIT}_{\mathrm{t}-1}$ & $\begin{array}{c}0.290 * * * \\
(0.0849)\end{array}$ & $\begin{array}{l}-0.160 \\
(0.104)\end{array}$ & $\begin{array}{c}0.303 * * * \\
(0.0836)\end{array}$ & $\begin{array}{l}-0.230 \\
(0.117)\end{array}$ \\
\hline Deficitt-1 & $\begin{array}{c}-0.115 \\
(0.0888)\end{array}$ & $\begin{array}{c}0.0703 \\
(0.0794)\end{array}$ & $\begin{array}{l}-0.176^{*} \\
(0.0942)\end{array}$ & $\begin{array}{c}0.0511 \\
(0.0820)\end{array}$ \\
\hline CITcut & $\begin{array}{c}-0.470 \\
(0.555)\end{array}$ & $\begin{array}{c}-1.843^{*} \\
(1.082)\end{array}$ & $\begin{array}{c}-0.373 \\
(0.552)\end{array}$ & $\begin{array}{c}-2.024 * * \\
(1.026)\end{array}$ \\
\hline CITinc & $\begin{array}{l}-0.119 \\
(0.540)\end{array}$ & $\begin{array}{c}1.370 * * \\
(0.430)\end{array}$ & $\begin{array}{l}-0.0530 \\
(0.577)\end{array}$ & $\begin{array}{c}1.409 * * \\
(0.436)\end{array}$ \\
\hline FedPITcut & $\begin{array}{c}-1.208 \\
(0.776)\end{array}$ & $\begin{array}{c}2.298 * * * \\
(0.472)\end{array}$ & $\begin{array}{l}-1.056 \\
(0.802)\end{array}$ & $\begin{array}{c}2.304 * * * \\
(0.490)\end{array}$ \\
\hline Grant $^{a}$ & $\begin{array}{c}0.168 \\
(0.390)\end{array}$ & $\begin{array}{c}-0.333 \\
(0.445)\end{array}$ & $\begin{array}{c}-0.00812 \\
(0.437)\end{array}$ & $\begin{array}{c}-0.698 \\
(0.593)\end{array}$ \\
\hline OtherPIT ${ }_{t-1}$ & $\begin{array}{c}-0.235 * * \\
(0.118)\end{array}$ & $\begin{array}{l}0.0670 \\
(0.125)\end{array}$ & $\begin{array}{c}-0.284 * * \\
(0.119)\end{array}$ & $\begin{array}{c}0.125 \\
(0.134)\end{array}$ \\
\hline OtherPITcut & $\begin{array}{c}1.432 * \\
(0.833)\end{array}$ & $\begin{array}{c}-0.198 \\
(0.729)\end{array}$ & $\begin{array}{c}1.423 \\
(0.883)\end{array}$ & $\begin{array}{c}-0.740 \\
(0.783)\end{array}$ \\
\hline OtherPITinc & $\begin{array}{c}0.114 \\
(0.909)\end{array}$ & $\begin{array}{c}0.533 \\
(0.727)\end{array}$ & $\begin{array}{c}0.150 \\
(0.967)\end{array}$ & $\begin{array}{l}-0.0571 \\
(0.763)\end{array}$ \\
\hline Left & $\begin{array}{c}-0.886 * * \\
(0.417)\end{array}$ & $\begin{array}{l}0.730 * \\
(0.380)\end{array}$ & $\begin{array}{c}-1.044^{* *} \\
(0.452)\end{array}$ & $\begin{array}{c}0.814 * * \\
(0.393)\end{array}$ \\
\hline Election & $\begin{array}{c}0.203 \\
(0.378)\end{array}$ & $\begin{array}{l}0.0222 \\
(0.393)\end{array}$ & $\begin{array}{c}0.207 \\
(0.388)\end{array}$ & $\begin{array}{l}0.0564 \\
(0.419)\end{array}$ \\
\hline Election $_{\mathrm{t}+1}$ & $\begin{array}{c}0.171 \\
(0.392)\end{array}$ & $\begin{array}{l}0.0661 \\
(0.397)\end{array}$ & $\begin{array}{c}0.188 \\
(0.396)\end{array}$ & $\begin{array}{c}0.137 \\
(0.388)\end{array}$ \\
\hline Constant & $\begin{array}{l}-2.346 \\
(1.903)\end{array}$ & $\begin{array}{c}0.503 \\
(2.003)\end{array}$ & $\begin{array}{l}-0.323 \\
(2.298)\end{array}$ & $\begin{array}{l}-0.722 \\
(2.273)\end{array}$ \\
\hline Provincial effects & \multicolumn{2}{|c|}{ Yes } & \multicolumn{2}{|c|}{ Yes } \\
\hline Other covariates & \multicolumn{2}{|c|}{ No } & \multicolumn{2}{|c|}{ Yes } \\
\hline Number of observations & \multicolumn{2}{|c|}{370} & \multicolumn{2}{|c|}{370} \\
\hline Percent correctly predicted & \multicolumn{2}{|c|}{64.6} & \multicolumn{2}{|c|}{66.67} \\
\hline Log-likelihood value & \multicolumn{2}{|c|}{-265.53} & \multicolumn{2}{|c|}{-258.32} \\
\hline Pseudo R-squared & \multicolumn{2}{|c|}{0.21} & \multicolumn{2}{|c|}{0.23} \\
\hline
\end{tabular}

Notes: Dependent variable is the probability to lower tax rate (category $=1)$ and raise tax rate (category $=3$ ) relative to the probability of holding the tax rate unchanged (in logs). Variables without time subscripts enter the regression contemporaneously. Robust asymptotic standard errors in parentheses. ${ }^{*} p<0.10, * \star p<0.05, * \star * p<0.001$. In columns (3) and (4) we include the unemployment rate, changes in total population, the share of the young (population under 10 years of age), the share of the old (population who are 65 and above years of age) as additional covariates.

a multiplied by 1000 
TABLE 4: MULTINOMIAL LOGIT ESTIMATES FOR CIT RATE CHANGES, 1973-2010

\begin{tabular}{|c|c|c|c|c|}
\hline & $\begin{array}{l}\text { Lower CIT rate } \\
\text { (1) }\end{array}$ & $\begin{array}{l}\text { Raise CIT rate } \\
\text { (2) }\end{array}$ & $\begin{array}{c}\text { Lower CIT rate } \\
\text { (3) }\end{array}$ & $\begin{array}{c}\text { Raise CIT rate } \\
\text { (4) }\end{array}$ \\
\hline $\mathrm{CIT}_{\mathrm{t}-1}$ & $\begin{array}{c}0.202 \\
(0.152)\end{array}$ & $\begin{array}{c}-0.355^{* *} \\
(0.124)\end{array}$ & $\begin{array}{c}0.188 \\
(0.149)\end{array}$ & $\begin{array}{c}-0.348^{* *} \\
(0.122)\end{array}$ \\
\hline Deficitt-1 & $\begin{array}{c}-0.289 * * \\
(0.107)\end{array}$ & $\begin{array}{l}0.0871 \\
(0.116)\end{array}$ & $\begin{array}{l}-0.212^{*} \\
(0.125)\end{array}$ & $\begin{array}{l}0.0833 \\
(0.133)\end{array}$ \\
\hline PITcut & $\begin{array}{c}-0.616 \\
(0.719)\end{array}$ & $\begin{array}{c}-0.339 \\
(0.616)\end{array}$ & $\begin{array}{c}-0.495 \\
(0.750)\end{array}$ & $\begin{array}{c}-0.445 \\
(0.628)\end{array}$ \\
\hline PITinc & $\begin{array}{l}-1.543 \\
(1.085)\end{array}$ & $\begin{array}{c}1.512 * * * \\
(0.459)\end{array}$ & $\begin{array}{l}-1.789 * \\
(1.069)\end{array}$ & $\begin{array}{c}1.535^{* *} \\
(0.478)\end{array}$ \\
\hline FedCITcut & $\begin{array}{c}1.258 * * \\
(0.528)\end{array}$ & $\begin{array}{c}0.229 \\
(0.392)\end{array}$ & $\begin{array}{c}1.253 * * \\
(0.549)\end{array}$ & $\begin{array}{c}0.223 \\
(0.393)\end{array}$ \\
\hline FedCITinc & $\begin{array}{l}-0.585 \\
(1.280)\end{array}$ & $\begin{array}{c}0.817 \\
(0.659)\end{array}$ & $\begin{array}{l}-0.796 \\
(1.381)\end{array}$ & $\begin{array}{c}0.809 \\
(0.663)\end{array}$ \\
\hline Grant $^{a}$ & $\begin{array}{l}1.14^{* *} \\
(0.490)\end{array}$ & $\begin{array}{c}-0.514 \\
(0.548)\end{array}$ & $\begin{array}{c}1.33^{* *} \\
(0.589)\end{array}$ & $\begin{array}{c}-0.633 \\
(0.661)\end{array}$ \\
\hline OtherClT $\mathrm{t}_{\mathrm{t}-1}$ & $\begin{array}{c}0.208 \\
(0.188)\end{array}$ & $\begin{array}{c}0.185 \\
(0.156)\end{array}$ & $\begin{array}{c}0.222 \\
(0.179)\end{array}$ & $\begin{array}{c}0.202 \\
(0.161)\end{array}$ \\
\hline OtherCITcut & $\begin{array}{c}2.321 * * \\
(1.139)\end{array}$ & $\begin{array}{c}3.395^{* *} \\
(1.340)\end{array}$ & $\begin{array}{l}2.337^{*} \\
(1.198)\end{array}$ & $\begin{array}{c}3.312^{* *} \\
(1.339)\end{array}$ \\
\hline OtherCITinc & $\begin{array}{l}2.050 * \\
(1.133)\end{array}$ & $\begin{array}{c}3.315^{* *} \\
(1.303)\end{array}$ & $\begin{array}{l}2.223^{*} \\
(1.218)\end{array}$ & $\begin{array}{c}3.127^{* *} \\
(1.342)\end{array}$ \\
\hline Left & $\begin{array}{c}0.725 \\
(0.569)\end{array}$ & $\begin{array}{l}-0.105 \\
(0.415)\end{array}$ & $\begin{array}{c}0.752 \\
(0.585)\end{array}$ & $\begin{array}{l}-0.113 \\
(0.429)\end{array}$ \\
\hline Election & $\begin{array}{c}0.379 \\
(0.530)\end{array}$ & $\begin{array}{c}-0.383 \\
(0.443)\end{array}$ & $\begin{array}{c}0.472 \\
(0.539)\end{array}$ & $\begin{array}{c}-0.461 \\
(0.459)\end{array}$ \\
\hline Election $_{t+1}$ & $\begin{array}{c}0.183 \\
(0.534)\end{array}$ & $\begin{array}{c}-0.685 \\
(0.460)\end{array}$ & $\begin{array}{c}0.200 \\
(0.529)\end{array}$ & $\begin{array}{c}-0.793^{*} \\
(0.469)\end{array}$ \\
\hline Constant & $\begin{array}{c}-11.26 * * * \\
(3.168)\end{array}$ & $\begin{array}{l}-2.069 \\
(1.937)\end{array}$ & $\begin{array}{c}-11.96 * * * \\
(3.540)\end{array}$ & $\begin{array}{l}-3.700 \\
(2.424)\end{array}$ \\
\hline Provincial effects & \multicolumn{2}{|c|}{ Yes } & \multicolumn{2}{|c|}{ Yes } \\
\hline Other covariates & \multicolumn{2}{|c|}{ No } & \multicolumn{2}{|c|}{ Yes } \\
\hline Number of observations & \multicolumn{2}{|c|}{370} & \multicolumn{2}{|c|}{370} \\
\hline Percent correctly predicted & \multicolumn{2}{|c|}{75.4} & \multicolumn{2}{|c|}{76.41} \\
\hline Log-likelihood value & \multicolumn{2}{|c|}{-178.55} & \multicolumn{2}{|c|}{-176.30} \\
\hline Pseudo R-squared & \multicolumn{2}{|c|}{0.28} & \multicolumn{2}{|c|}{0.29} \\
\hline
\end{tabular}

Notes: Dependent variable is the probability to lower tax rate (category $=1$ ) and raise tax rate (category $=3$ ) relative to the probability of holding the tax rate unchanged (in logs). Variables without time subscripts enter the regression contemporaneously. Robust asymptotic standard errors in parentheses. ${ }^{*} p<0.10, * \star p<0.05, * \star \star p<0.001$. In columns (3) and (4) we include the unemployment rate, changes in total population, the share of the young (population under 10 years of age), the share of the old (population who are 65 and above years of age) as additional covariates.

a multiplied by 1000 
TABLE 5: MULTINOMIAL LOGIT ESTIMATES FOR PST RATE CHANGES, 1973-2010

\begin{tabular}{|c|c|c|c|c|}
\hline & $\begin{array}{l}\text { Lower PST rate } \\
\text { (1) }\end{array}$ & $\begin{array}{l}\text { Raise PST rate } \\
\text { (2) }\end{array}$ & $\begin{array}{c}\text { Lower PST rate } \\
\text { (3) }\end{array}$ & $\begin{array}{c}\text { Raise PST rate } \\
\text { (4) }\end{array}$ \\
\hline $\mathrm{PST}_{\mathrm{t}-1}$ & $\begin{array}{c}1.852 * * \\
(0.663)\end{array}$ & $\begin{array}{c}-0.736 * * \\
(0.253)\end{array}$ & $\begin{array}{c}2.253^{* *} \\
(0.785)\end{array}$ & $\begin{array}{c}-0.952 * * * \\
(0.250)\end{array}$ \\
\hline Deficitt-1 & $\begin{array}{c}-0.628 * * \\
(0.200)\end{array}$ & $\begin{array}{c}0.352 * * \\
(0.130)\end{array}$ & $\begin{array}{c}-0.655^{* *} \\
(0.207)\end{array}$ & $\begin{array}{c}0.335^{* *} \\
(0.114)\end{array}$ \\
\hline Grant $^{a}$ & $\begin{array}{l}1.580 * * \\
(0.687)\end{array}$ & $\begin{array}{c}-0.0919 \\
(0.367)\end{array}$ & $\begin{array}{c}0.881 \\
(0.971)\end{array}$ & $\begin{array}{c}0.424 \\
(0.422)\end{array}$ \\
\hline OtherPST ${ }_{t-1}$ & $\begin{array}{c}0.002 \\
(0.409)\end{array}$ & $\begin{array}{l}0.677^{*} \\
(0.354)\end{array}$ & $\begin{array}{c}0.446 \\
(0.463)\end{array}$ & $\begin{array}{c}0.643 \\
(0.446)\end{array}$ \\
\hline OtherPSTcut & $\begin{array}{l}1.265^{* *} \\
(0.634)\end{array}$ & $\begin{array}{c}0.273 \\
(0.890)\end{array}$ & $\begin{array}{c}1.250 \\
(0.813)\end{array}$ & $\begin{array}{c}0.507 \\
(0.972)\end{array}$ \\
\hline OtherPSTinc & $\begin{array}{l}-0.0155 \\
(0.771)\end{array}$ & $\begin{array}{l}1.105^{* *} \\
(0.542)\end{array}$ & $\begin{array}{c}0.105 \\
(0.847)\end{array}$ & $\begin{array}{l}1.050 * \\
(0.574)\end{array}$ \\
\hline Left & $\begin{array}{c}-1.640 * * \\
(0.659)\end{array}$ & $\begin{array}{c}0.517 \\
(0.472)\end{array}$ & $\begin{array}{c}-2.255^{* *} \\
(0.796)\end{array}$ & $\begin{array}{c}0.526 \\
(0.595)\end{array}$ \\
\hline Election & $\begin{array}{c}0.776 \\
(0.621)\end{array}$ & $\begin{array}{c}-1.829 * * \\
(0.771)\end{array}$ & $\begin{array}{c}0.767 \\
(0.610)\end{array}$ & $\begin{array}{c}-1.983^{* *} \\
(0.769)\end{array}$ \\
\hline Election $_{t+1}$ & $\begin{array}{c}0.486 \\
(0.587)\end{array}$ & $\begin{array}{l}-0.621 \\
(0.469)\end{array}$ & $\begin{array}{c}0.332 \\
(0.595)\end{array}$ & $\begin{array}{c}-0.639 \\
(0.489)\end{array}$ \\
\hline Constant & $\begin{array}{c}-15.44 * * \\
(4.973)\end{array}$ & $\begin{array}{c}2.512 \\
(1.621)\end{array}$ & $\begin{array}{c}-12.16 * * \\
(5.477)\end{array}$ & $\begin{array}{l}-2.038 \\
(2.187)\end{array}$ \\
\hline Provincial effects & \multicolumn{2}{|c|}{ Yes } & \multicolumn{2}{|c|}{ Yes } \\
\hline Other covariates & \multicolumn{2}{|c|}{ No } & \multicolumn{2}{|c|}{ Yes } \\
\hline Number of observations & \multicolumn{2}{|c|}{370} & \multicolumn{2}{|c|}{370} \\
\hline Percent correctly predicted & \multicolumn{2}{|c|}{81.8} & \multicolumn{2}{|c|}{85.13} \\
\hline Log-likelihood value & \multicolumn{2}{|c|}{-137.64} & \multicolumn{2}{|c|}{-128.16} \\
\hline Pseudo R-squared & \multicolumn{2}{|c|}{0.26} & \multicolumn{2}{|c|}{0.31} \\
\hline
\end{tabular}

Notes: Dependent variable is the probability to lower tax rate (category $=1$ ) and raise tax rate (category $=3$ ) relative to the probability of holding the tax rate unchanged (in logs). Variables without time subscripts enter the regression contemporaneously. Robust asymptotic standard errors in parentheses. ${ }^{\star} p<0.10,{ }^{\star} \neq p<0.05, \star \star \star p<0.001$. In columns (3) and (4) we include the unemployment rate, changes in total population, the share of the young (population under 10 years of age), the share of the old (population who are 65 and above years of age) as additional covariates.

a multiplied by 1000

TABLE 6: AVERAGE PREDICTED PROBABILITIES OF TAX RATE CUTS AND INCREASES, 1973-2010

\begin{tabular}{|l|c|c|c|c|c|c|}
\hline Province & CIT cut & CIT increase & PIT cut & PIT increase & PST cut & PST increase \\
\hline NFL & 0.0541 & 0.1351 & 0.1081 & 0.3243 & 0.0270 & 0.1081 \\
PEI & 0.0000 & 0.0541 & 0.0541 & 0.2432 & 0.0541 & 0.0811 \\
NS & 0.0000 & 0.1081 & 0.1351 & 0.1622 & 0.0541 & 0.0811 \\
NB & 0.1081 & 0.1622 & 0.2432 & 0.2162 & 0.0541 & 0.0811 \\
QB & 0.0811 & 0.2703 & 0.1892 & 0.0541 & 0.1081 & 0.0540 \\
ON & 0.0541 & 0.1351 & 0.1622 & 0.3784 & 0.0270 & 0.0811 \\
MB & 0.1892 & 0.0811 & 0.1622 & 0.0811 & 0.0270 & 0.0811 \\
SK & 0.1351 & 0.1351 & 0.2703 & 0.1081 & 0.1081 & 0.1351 \\
AB & 0.1351 & 0.0811 & 0.1622 & 0.0811 & 0.0000 & 0.0000 \\
BC & 0.1351 & 0.1351 & 0.2432 & 0.2973 & 0.1081 & 0.1081 \\
All provinces & $\mathbf{0 . 0 8 9 2}$ & $\mathbf{0 . 1 2 9 7}$ & $\mathbf{0 . 1 7 3 0}$ & $\mathbf{0 . 1 9 4 6}$ & $\mathbf{0 . 0 5 6 8}$ & $\mathbf{0 . 0 8 3 8}$ \\
\hline
\end{tabular}

Note: The probabilities are the average values for the period 1973-2010 and computed based on log-odds ratio estimates of Tables 3-5. 
Our empirical results show that a provincial government's lagged deficit-to-GDP ratio (Deficit $t_{-1}$ ) has no statistically significant effect on PIT rate cuts and increases. However, as expected, the variable is negative and statistically significant in the CIT rate-cut equation but it is not significant in the CIT rate-increase equation. This result reflects a feature of the simple model of the previous section, which predicted that a provincial government may have asymmetric responses to changes in its fiscal environment. The results indicate that provincial governments with a higher deficit-to-GDP ratio are less likely to cut the CIT rate rather than leave it unchanged. Our model indicates that a one percentage point increase in the deficit ratio would reduce the probability of a CIT rate cut by 3.4 percentage points in Alberta and 1.5 percentage points in Ontario. It would raise the probability of a CIT rate increase by less than one percentage point in both provinces. Table 5 also shows that a provincial government's lagged deficit-to-GDP ratio has statistically significant effects on the likelihood of sales tax rate cuts and increases. Our model indicates that in Ontario a one percentage point increase in the deficit ratio would reduce the probability of a PST rate cut by 1.7 percentage points, and raise the probability of a PST rate increase by 2.8 percentage points.

While federal grants per capita (Grant) seem to have no statistically significant effects on PIT rate changes, they have significant effects in the CIT and PST rate-cut equations. The results in column (1) of Table 4 show that higher real federal grants per capita increase the probability of a CIT rate cut rather than leave it unchanged. The model implies that if the annual real federal grant per capita increases by $\$ 100$, the probability of a CIT rate cut would increase by 1.3 percentage points in Alberta and by 0.5 percentage points in Ontario. Similarly, Table 5 shows that the federal grants per capita variable has a statistically significant effect only in the PST rate- cut equation in column (1). However, the estimated increase in the probability of a PST rate cut would be less than one percentage point for a $\$ 100$ per-capita grant increase.

A provincial government's likelihood of changing the PIT rate may well depend on what happens to the CIT rate and vice versa, as the link between the two taxes is often viewed as important for maintaining the integrity of the income tax system. In order to check the effects of corporate income tax rate changes on the likelihood of PIT rate changes, in Table 3 we include two dummy variables. The first one is a dummy variable (CITCut) that is equal to one if the province cuts the CIT rate and zero otherwise. The second variable (CITinc) is also a dummy variable that is equal to one if the province raises the CIT rate and zero otherwise. Similarly, to check the influence of PIT rate changes on the likelihood of CIT changes, in Table 4 we include two dummy variables: one for a PIT cut and another for a PIT increase.

Regression results in Table 3 shows that the coefficient estimates for both CITcut and CITinc variables are not statistically significant in the PIT rate-cut equation, suggesting that contemporaneous changes in the CIT rate do not affect the likelihood of PIT rate cut. However, the coefficient estimates of CITCut and CITinc are statistically significant at the 10 and five per cent levels in column (2) of Table 3. These results suggest that while a cut in the CIT rate reduces the likelihood of PIT rate increase, an increase in the CIT rate raises the likelihood of a PIT rate increase. The implication is that provinces tend to increase PIT and CIT rates together to maintain the integrity of the income tax system while raising additional tax revenues, whereas a CIT rate cut (weakly) reduces the likelihood of a PIT rate increase. 
In Table 4, on the other hand, the coefficient of PITinc is positive and statistically significant at the one per cent level in the CIT rate-increase equation. For Alberta, our model indicates that a PIT rate increase reduces the probability of a CIT rate cut by 1.7 percentage points and raises the probability of a CIT rate increase by 11.3 percentage points. For Ontario, it would reduce the probability of a CIT rate cut by 11 percentage points and increase the probability of a CIT rate increase by 17.7 percentage points. The coefficient estimates of PITcut are not statistically significant in either equation. This seems to indicate that provincial governments tend to raise PIT and CIT rates at the same time, while PIT rate reductions are not coordinated with CIT rate cuts.

\subsection{Federal Tax Policy}

For the PIT, we include a dummy variable (FedPITcut) that is equal to one if the federal government cuts its PIT rate in the current period and zero otherwise as an explanatory variable. During the period under consideration, the federal government cut its PIT rate only three times (in 1977, 1982, and 1988) and it did not raise its PIT rate. Thus we only include a dummy variable when there is a federal PIT cut. In 1977, as part of the introduction of the Established Program Financing (EPF) grants, the federal government cut its PIT and CIT rates, which enabled the provinces to take up the vacated federal tax room. ${ }^{36}$ Unlike the federal PIT reform of 1977, the 1982 and 1987 federal PIT cuts were not coordinated with tax changes with the provincial governments or changes to the grant system.

The regression results of Table 3 suggest that FedPITcut is positive and statistically significant in the PIT rate-increase equation. This indicates that a provincial government is more likely to raise its PIT rate when the federal government lowers its PIT rate. For Alberta, a cut in the federal PIT rate reduces the probability of a provincial PIT rate cut by three percentage points and increases the probability of a PIT rate increase by 17.1 percentage points. For Ontario, a federal PIT rate cut reduces the probability of a provincial PIT rate cut by 14.1 per cent and increases the probability of a provincial PIT rate increase by 54.1 percentage points. This is consistent with the view that provinces move in to fill the room created by federal PIT cuts. One may wonder if the response of the provincial governments to the 1977 federal tax reform was the sole reason for the observed positive coefficient of the FedPITcut variable. However, in a separate regression not reported in Table 3, we find that even after controlling for the effect of the 1977 reform using a dummy variable, the coefficient of FedPITcut is still positive and statistically significant.

With respect to CIT, the federal government has both reduced and increased its rate during the period under study. Thus we include two control variables. The first one is, FedCITcut, a dummy variable that is equal to one if there is a federal CIT cut or zero otherwise. Similarly, the second variable (FedCITinc) is equal to one if there is a federal CIT rate increase or zero otherwise. Thus the omitted reference point is the category of no federal CIT rate change.

\footnotetext{
36 See http://www.fin.gc.ca/fedprov/his-eng.asp on the history of the 1977 EPF reforms.
} 
The regression results in Table 4 indicate that there are different responses to federal PIT and CIT rate cuts. The coefficient estimate of FedCITcut is positive and statistically significant in the CIT rate-cut equation, indicating that provincial governments are more likely to cut their CIT rates when the federal government cuts its CIT rate. The dummy variable for a federal CIT increase has the expected signs in both equations. However, it is not statistically significant in either equation. Our model indicates that in response to a cut in the federal CIT rate, the probability of Alberta cutting its CIT rate increases by 14.7 percentage points and the probability of a provincial CIT rate increase falls by 1.4 percentage points. For Ontario, a federal CIT rate cut increases the probability of a provincial CIT rate cut by 6.4 percentage points and lowers the probability of a provincial CIT rate increase by about one percentage point.

\subsection{Other Provinces' Tax Policies}

How responsive are provincial governments to tax rate changes by other provinces? Table 4 shows that the coefficient estimates of lagged tax CIT rates of other provinces (OtherCIT $T_{t-1}$ ) are not statistically significant in either CIT rate-cut or increase equations. On the other hand, Tables 3 and 5 respectively show that lagged PIT (OtherPIT $\left.T_{t-1}\right)$ and lagged PST (OtherPIT $\left.T_{t-1}\right)$ of other provinces are statistically significant in their respective tax rate-cut and tax rateincrease equations. These results suggest that a province is less likely to cut its PIT rate when the average PIT rate of other provinces is high. For Alberta and Ontario, a one percentage point increase in other provinces' PIT rates lowers the probability of a provincial PIT rate cut by 3.2 percentage points and has a negligible effect on the probability of a PIT rate increase. Similarly, Table 5 shows that the coefficient of neighbouring provinces' sales tax rates, OtherPST $T_{t-1}$, is positive and statistically significant in the tax rate-increase equation, indicating that a provincial government is more likely to raise its sales tax rate, rather than leave it unchanged, when its neighbouring provinces' sales tax rates increase. For Ontario, an increase in other provinces' PST rates increases the probability of a provincial PST rate increase by 8.2 per cent and has a negligible effect on the probability of a PST rate cut.

As an alternative way of assessing the importance of horizontal tax competition, we included dummy variables that capture tax rate cuts and increases by other provinces as covariates. In Tables 3-5, these dummy variables for tax rate cuts by other provinces are OtherPITcut, OtherCITcut and OtherPSTcut. Similarly we include dummy variables OtherPITinc, OtherCITinc and OtherPSTinc to capture tax rate increases by other provinces. In all cases the omitted reference point is the category of no tax rate changes by other provinces. The regression results indicate that the coefficient of the dummy variable for a PIT rate cut by other provinces (OtherPITcut) is positive and statistically significant in the tax rate-cut equation at the 10 per cent level, but insignificant in the PIT rate increase equation. This suggests that a province is more likely to cut its PIT rate when other provinces cut their PIT rates. These horizontal competition variables are, however, not statistically significant in the tax rateincrease equation. In other words, our results provide weak empirical support for the proposition that provinces tend to match PIT tax rate cuts, rather than increases made by other provinces. 
Table 4 indicates that, consistent with the corporate tax rate competition literature, a cut in the CIT rate by other provinces makes a province more likely to cut its CIT rate. Similarly, provincial governments are more likely to raise their CIT rates, rather than leave them unchanged, when other provinces raise their CIT rates. However, the coefficient estimate for OtherCITcut is positive and significant in the tax rate-increase equation, which is inconsistent with our prior expectations, while the coefficient estimate of OtherCITinc is positive in the tax rate-cut equations, although it is significant only at the 10 per cent level.

\subsection{The Political Environment}

In this section, we describe our findings concerning the effects of political variables on the timing of tax rate changes. Recall that we have defined a dummy variable (Left) that is equal to one if the Premier of the province belongs to the Liberal Party or the New Democratic Party (NDP). Our results indicate that while the ideology of the governing party does not seem to have a statistically significant effect for CIT rate changes, it is important in explaining the probability of raising or lowering the PIT rate and lowering the PST rate. The coefficient estimate on Left for the PIT is negative in the tax rate-cut equation but positive in the tax rateincrease equation. In both cases the coefficient estimates are also statistically significant. The results suggest that provinces with left-leaning governing parties are less likely to cut the PIT rate and more likely to raise the PIT rate. Our model indicates that a Left government in Alberta would reduce the probability of a PIT rate cut by 12 percentage points and increase the probability of a PIT rate increase by 1.2 percentage points. For Ontario, a Left government also reduces the probability of a PIT rate cut by 12 percentage points and increases the probability of a PIT increase by 5.4 percentage points. The implication of our result is that ideology seems to matter - provinces with left-leaning governments are generally less likely to cut and more likely to raise the PIT rate.

The ideological dummy variable has the expected signs in both equations for PST, but it is statistically significant only in the tax rate-cut equation. Thus there is an asymmetrical response by provincial governments to the ideological variable. The result suggests that left-leaning provincial governments are less likely to cut the sales tax rate. Our model indicates that a Left government in Ontario raises the probability of a PST increase by 8.2 percentage points and would have a negligible effect on the probability of a PST cut.

In our analysis, we also include the timing of elections as additional political control variables. The results in Tables 3-5 show that the two election dummy variables do not seem to have statistically significant effects on the likelihood of PIT and CIT rate changes. However, the coefficient estimate of election dummy for the current year is negative and statistically significant in the PST rate-increase equation. This suggests that provincial governments are less likely to raise the sales tax rate, rather than leave it unchanged when there is an election in the current year. The reason may be partly due to the widely held perception that these taxes are unfair to low-income people. This makes them a less popular choice during election years. For Ontario, a PST rate increase is 13.6 percentage points lower in an election year. 
So far, our set of control variables includes those variables that account for the province's fiscal position, political environment, and vertical and horizontal tax competition. However, one may argue that it is important to control for demographic variables to capture the fiscal needs of provincial governments. To address this concern, in columns (3) and (4) of Tables 3-5 we include the unemployment rate, changes in total population, the share of the young (population under 10 years of age), and the share of the old (population who are 65 and above years of age) as additional covariates.

The regression results of columns (3) and (4) are qualitatively similar to those of columns (1) and (2), respectively. There are, however, some minor changes that occur as a result of including additional covariates. For PIT regression, the coefficient of the lagged deficit-to-GDP ratio is now, as expected, negative and statistically significant at the 10 per cent level in the PIT rate-cut equation. In the CIT regression, on the other hand, comparison of columns (3) and (4) with the corresponding results of columns (1) and (2) reveal that now the variable PITcut is negative and significant at the 10 per cent level. Finally, for the PST regression, the only change is that the coefficient of federal grants per capita becomes statistically insignificant in the PST cut equation once we control for the demographic covariates. Thus, our results seem to be generally robust to the inclusion of additional covariates.

\section{CONCLUSIONS}

The literature on optimal taxation suggests that tax rates should be continuously adjusted by governments so that the marginal cost of public funds is equalized across tax bases and is equal to the marginal benefit of government spending financed by the tax revenue. In practice, statutory tax rate changes are not that common. In fact, tax rates tend to be "sticky," a characteristic that is not consistent with the normative theory of optimal taxation or with conventional models of tax competition by subnational governments. Why are tax rates so "sticky?" What factors induce government to change their tax rates?

In this this paper we examine the factors that influence governments' decision to lower or raise statutory tax rates. Our paper makes two important contributions to the literature. First, we develop a simple theoretical model that explains why statutory tax rates tend to be "sticky." We assume that governments embark on a tax reform by comparing the gains from adjusting tax rates with the associated fixed costs of the reform. Tax rates tend to be "sticky" if the cost of the tax reform outweighs the potential benefit from the reform. The likelihood of a tax rate change is affected by variables which determine the optimal tax rate and by variables that affect the cost of introducing a tax rate change.

Second, we empirically investigate the likelihood of tax rate changes using multinomial logit regression model for Canadian provincial governments over the period 1973-2010. The choice of this empirical approach is justified on the grounds that governments face three distinctive choices about tax rate changes: to lower the tax rate, to raise the tax rate, or to keep the tax rate unchanged. To the best of our knowledge, our paper is the first to investigate the likelihood of tax rate changes in a multi-category discrete tax rate setting. We focus on the three major taxes used by Canadian provincial governments: personal income tax rates, corporate income tax rates, and general sales tax rates. 
Our empirical analysis shows that the fiscal position of the provinces, political variables, and the tax policies of the federal government and other provincial governments in the federation influence the likelihood of tax rate changes. We argue that for these reasons, variables affect the costs and benefits associated with tax reform, and the empirical results are broadly consistent with the simple model outlined in Section 2. Regarding the impact of the fiscal position of the province on the likelihood of a tax reform, we find that a weaker fiscal position, as manifested by a higher provincial budget deficit-to-GDP ratio, reduces the probability of a CIT rate cut and raises the probability of a PST rate increase. This may be driven by the need to raise more tax revenues in the face of higher budget deficits. Surprisingly, we do not find a similar effect of deficits on the PIT.

For politicians, the cost of a tax reform is its effect on the probability of winning an election. Surprisingly, however, our results show that whether provincial governments face elections in the current or following year does not matter for the likelihood of PIT and CIT changes. But, consistent with the general perception that sales taxes are unpopular, our results indicate that provincial governments are less likely to raise sales taxes during an election year. The ideology of the provincial government also seems to matter in the likelihood of embarking on tax reforms. We find that provinces with left-leaning governments are less likely to cut PIT and PST rates, and more likely to raise PIT rates compared to non-left-leaning governments.

Another important finding of our paper is the response of provincial governments to tax rate changes by the federal government. Our results suggest that provincial governments have different responses to federal PIT and CIT cuts. While federal CIT cuts raise the likelihood of provincial CIT cuts, federal PIT cuts raise the likelihood of provincial PIT increases. The latter is consistent with the view that provinces move in to fill the room created by federal PIT cuts. Furthermore, consistent with the horizontal competition literature, we find that provincial governments are more likely to cut their PIT and CIT rates when their neighbours lower their rates. Provinces are also more likely to increase their PST rates when their neighbours raise their rates.

In sum, the empirical results for the three major taxes used by Canadian provincial governments are broadly consistent with our simple model, and highlight the factors that are likely to influence provincial governments' decisions to embark on tax rate reforms. In general, the fiscal position of the government, its political orientation and tax rate changes by the federal government and other provincial governments affect the likelihood of tax rate changes by a provincial government. While our model is the first to look at governments' tax rate decisions in a multi-choice setting, there are some shortcomings to be addressed in the future. First, our theoretical model deals specifically with commodity taxation. It also assumes that the adjustment costs are fixed. Although relaxing these assumptions is unlikely to change the empirical results, it may be important to relax this assumption and apply the model to income tax changes. Second, our empirical model does not explicitly model the political costs of a tax rate change or deal with the dynamics of tax reform. Third, tax rate changes by provincial governments and the federal government may occur simultaneously, and this may create the usual endogeneity problems. Some of these limitations can be good avenues for future researches exploring tax adjustments and the various associated costs and benefits of tax reforms. 


\section{APPENDIX 1: DEFINITIONS OF VARIABLES AND DATA SOURCES}

\begin{tabular}{|c|c|c|}
\hline Variable & Description & Source \\
\hline Population & Total provincial population & CANSIM Table 051-0001. \\
\hline $\begin{array}{l}\text { Corporate income tax rate } \\
\text { (CIT) }\end{array}$ & $\begin{array}{l}\text { Provincial statutory top marginal corporate income } \\
\text { tax rate (General rate) }\end{array}$ & $\begin{array}{l}\text { Finances of the Nation } \\
\text { (formerly National Finances) }\end{array}$ \\
\hline $\begin{array}{l}\text { Top personal income } \\
\text { marginal tax rate (PIT) }\end{array}$ & $\begin{array}{l}\text { Provincial income tax rate of the top income bracket } \\
\text { including applicable surtaxes }\end{array}$ & $\begin{array}{l}\text { Finances of the Nation } \\
\text { (formerly National Finances) }\end{array}$ \\
\hline Sales tax rate & Provincial sales tax rate (PST) & $\begin{array}{l}\text { Finances of the Nation } \\
\text { (formerly National Finances) }\end{array}$ \\
\hline Federal corporate tax rate & $\begin{array}{l}\text { Statutory top marginal corporate income tax rate } \\
\text { (General rate) levied by the federal government }\end{array}$ & $\begin{array}{l}\text { Finances of the Nation } \\
\text { (formerly National Finances) }\end{array}$ \\
\hline $\begin{array}{l}\text { Federal top personal } \\
\text { marginal tax rate }\end{array}$ & Federal income tax rate of the top income bracket & $\begin{array}{l}\text { Finances of the Nation } \\
\text { (formerly National Finances) }\end{array}$ \\
\hline Other provinces' CIT & $\begin{array}{l}\text { The weighted average (weighed by the inverse of the } \\
\text { distance between major population centres) CIT of } \\
\text { other provinces in the federation }\end{array}$ & $\begin{array}{l}\text { Computed from provincial CIT } \\
\text { data }\end{array}$ \\
\hline Other provinces' PIT & $\begin{array}{l}\text { The weighted average (weighed by the inverse of the } \\
\text { distance between major population centers) PIT of } \\
\text { other provinces in the federation }\end{array}$ & $\begin{array}{l}\text { Computed from provincial PIT } \\
\text { data }\end{array}$ \\
\hline Other provinces' PST & $\begin{array}{l}\text { The weighted average (weighed by the inverse of the } \\
\text { distance between major population centers) PST of } \\
\text { contiguous provinces }\end{array}$ & $\begin{array}{l}\text { Computed from provincial } \\
\text { sales tax data }\end{array}$ \\
\hline Budget Deficit & Provincial government budget deficit & $\begin{array}{l}\text { Statistics Canada CANSIM } \\
\text { Table 385-0001 }\end{array}$ \\
\hline Grants & Federal grants to the provinces & $\begin{array}{l}\text { Statistics Canada CANSIM } \\
\text { Table 384-0011 }\end{array}$ \\
\hline Election & Dummy variable for election years & $\begin{array}{l}\text { Canadian Parliamentary } \\
\text { Guide }\end{array}$ \\
\hline Left & $\begin{array}{l}\text { A dummy variable that is equal to one if the Premier } \\
\text { of the province belongs to the NDP or the Liberal } \\
\text { Parties }\end{array}$ & $\begin{array}{l}\text { Canadian Parliamentary } \\
\text { Guide }\end{array}$ \\
\hline
\end{tabular}




\section{APPENDIX 2: PREVIOUS EMPIRICAL STUDIES OF THE DETERMINANTS OF TAX RATE CHANGES}

\begin{tabular}{|c|c|c|c|}
\hline Study & Data & Statistical Technique & Key Results \\
\hline $\begin{array}{l}\text { Castanheira, } \\
\text { Nicodème, and } \\
\text { Profeta (2012) }\end{array}$ & $\begin{array}{l}\text { Changes to personal } \\
\text { income tax and social } \\
\text { security tax systems for } \\
27 \text { EU countries between } \\
2000 \text { and } 2007 .\end{array}$ & $\begin{array}{l}\text { Logistic regression } \\
\text { model }\end{array}$ & $\begin{array}{l}\text { The likelihood of a tax change is lower when } \\
\text { governments are in power for longer times } \\
\text { between elections, and when either a left- } \\
\text { wing or a right-wing government is in power; } \\
\text { the occurrence of tax changes was not linked } \\
\text { to the timing of elections; the number of } \\
\text { political parties in a coalition government } \\
\text { was a better predictor of reforms than either } \\
\text { the measures of the business cycle, labour } \\
\text { market pressures or other socioeconomic } \\
\text { variables. }\end{array}$ \\
\hline $\begin{array}{l}\text { Heinemann, } \\
\text { Overesch, and } \\
\text { Rincke (2010) }\end{array}$ & $\begin{array}{l}\text { Changes to the statutory } \\
\text { corporate income tax rate } \\
\text { for up to } 32 \text { European } \\
\text { countries, } 1980 \text { to } 2007 \text {. }\end{array}$ & $\begin{array}{l}\text { Probit, fixed effects } \\
\text { logit, and linear } \\
\text { probability models }\end{array}$ & $\begin{array}{l}\text { Countries with high CIT rates are more likely } \\
\text { to reduce their rates; higher neighboring } \\
\text { countries' tax rates reduce the probability of } \\
\text { tax rate reductions; the probability for a cut } \\
\text { in the CIT rate is } 10 \text { to } 13 \text { percentage points } \\
\text { higher during an election period. }\end{array}$ \\
\hline $\begin{array}{l}\text { Devereux, } \\
\text { Lockwood, and } \\
\text { Redoano (2007) }\end{array}$ & $\begin{array}{l}\text { Increases in the nominal } \\
\text { tobacco and gasoline tax } \\
\text { rates by } 48 \text { US states, } \\
1977 \text { to } 1997 .\end{array}$ & Probit model & $\begin{array}{l}\text { A higher state tax rate lowers the probability } \\
\text { of a cigarette and gasoline tax rate increase; } \\
\text { a higher average state rate raise the } \\
\text { probability of a cigarette tax rate increase, } \\
\text { but does not have a significant effect on the } \\
\text { probability of a gasoline tax rate increase. A } \\
\text { higher per-capita grant lowers the probability } \\
\text { of a cigarette tax increase; Democrat control } \\
\text { of a state legislature raises the probability of } \\
\text { a cigarette tax rate increase. The probability } \\
\text { of a gasoline tax rate increase is lower when } \\
\text { the state income tax rate is higher. }\end{array}$ \\
\hline Adjei (2002) & $\begin{array}{l}\text { Personal income tax rate } \\
\text { changes by Canadian } \\
\text { provinces over the period } \\
1976-2006 .\end{array}$ & $\begin{array}{l}\text { Probit/logit and } \\
\text { Ordinary Least } \\
\text { Square }\end{array}$ & $\begin{array}{l}\text { The occurrence of personal income tax rate } \\
\text { (PIT) changes is affected by the federal PIT } \\
\text { rate; the magnitude of the tax rate changes } \\
\text { is mainly driven by the PIT rates of other } \\
\text { provinces. }\end{array}$ \\
\hline $\begin{array}{l}\text { Hassett and } \\
\text { Mathur (2007) }\end{array}$ & $\begin{array}{l}\text { Corporate income tax rate } \\
\text { cuts using a sample of } 68 \\
\text { countries over the period } \\
1981-2005 .\end{array}$ & Probit & $\begin{array}{l}\text { Countries that reduced their corporate } \\
\text { income tax rate in the past are more likely to } \\
\text { cut it again in the future; countries lower their } \\
\text { corporate income tax rate when their rates } \\
\text { deviate significantly from those of their } \\
\text { competitors. }\end{array}$ \\
\hline $\begin{array}{l}\text { Foremny and } \\
\text { Riedel (2012) }\end{array}$ & $\begin{array}{l}\text { Business tax rate changes } \\
\text { for German municipalities } \\
\text { over the period 2000- } \\
2008 \text {. }\end{array}$ & $\begin{array}{l}\text { Fixed effects and } \\
\text { Logit }\end{array}$ & $\begin{array}{l}\text { Tax rate growth falls during election years, but } \\
\text { increases after election years. }\end{array}$ \\
\hline
\end{tabular}




\section{APPENDIX 3: SUMMARY STATISTICS, 1972-2010}

\begin{tabular}{|c|c|c|c|c|c|c|}
\hline Variable & Definition & Obs & Mean & Std. Dev. & Min & Max \\
\hline RefPIT & $\begin{array}{l}\text { Dependent variable: "1" = PIT rate cut; } \\
\text { "2"= no PIT rate change; "3"= PIT rate increase }\end{array}$ & 380 & 2.0184 & 0.6009 & 1 & 3 \\
\hline RefCIT & $\begin{array}{l}\text { Dependent variable: "1" = CIT rate cut; } \\
\text { "2"= no CIT rate change; "3"= CIT rate increase }\end{array}$ & 380 & 2.0342 & 0.4667 & 1 & 3 \\
\hline RefPST & $\begin{array}{l}\text { Dependent variable: "1" = PST rate cut; } \\
\text { "2"= no PST rate change; "3"= PST rate increase }\end{array}$ & 380 & 2.0263 & 0.3695 & 1 & 3 \\
\hline $\mathrm{PIT}_{\mathrm{t}-1}$ & Lagged provincial statutory top PIT rate (\%) & 380 & 19.0788 & 4.1247 & 10.00 & 33.00 \\
\hline $\mathrm{CIT}_{\mathrm{t}-1}$ & Lagged provincial statutory CIT rate (\%) & 380 & 13.8352 & 2.6397 & 5.50 & 17.00 \\
\hline PST $_{-1}$ & Lagged provincial statutory PST rate (\%) & 380 & 7.2365 & 3.0013 & 0.00 & 12.00 \\
\hline Deficit $_{t-1}$ & Lagged deficit to GDP ratio (\%) & 380 & 0.9797 & 2.1109 & $\mid-6.5934$ & 9.3253 \\
\hline Grant & Federal Grant per capita (2002 dollars) & 390 & 1816 & 969 & 466 & 6314 \\
\hline Left & $\begin{array}{l}\text { Dummy=1 if the premier belongs to a left-leaning } \\
\text { party }\end{array}$ & 390 & 0.4923 & 0.5006 & 0 & 1 \\
\hline Election & $\begin{array}{l}\text { Dummy=1 if there is an election in the current } \\
\text { year }\end{array}$ & 390 & 0.2615 & 0.4400 & 0 & 1 \\
\hline Election $_{\mathrm{t}+1}$ & Dummy $=1$ if there is an election next year & 380 & 0.2632 & 0.4409 & 0 & 1 \\
\hline FedPITcut & $\begin{array}{l}\text { Dummy=1 if the federal government cuts its PIT } \\
\text { rate }\end{array}$ & 380 & 0.0789 & 0.2700 & 0 & 1 \\
\hline FedCITcut & $\begin{array}{l}\text { Dummy=1 if the federal government cuts its CIT } \\
\text { rate }\end{array}$ & 380 & 0.3684 & 0.4830 & 0 & 1 \\
\hline FedCITinc & $\begin{array}{l}\text { Dummy }=1 \text { if the federal government raises its } \\
\text { CIT rate }\end{array}$ & 380 & 0.1579 & 0.3651 & 0 & 1 \\
\hline OtherPIT $\mathrm{t}_{\mathrm{t}-1}$ & $\begin{array}{l}\text { Lagged weighted average PIT rate of other } \\
\text { provinces }(\%)\end{array}$ & 380 & 19.1386 & 2.2081 & 14.92 & 26.47 \\
\hline OtherCIT $\mathrm{t}_{\mathrm{t}-1}$ & $\begin{array}{l}\text { Lagged weighted average } \mathrm{CIT} \text { rate of other } \\
\text { provinces (\%) }\end{array}$ & 380 & 13.7222 & 1.4970 & 10.78 & 16.20 \\
\hline OtherPST $_{\mathrm{t}-1}$ & $\begin{array}{l}\text { Lagged weighted average PST rate of neighbouring } \\
\text { provinces (\%) }\end{array}$ & 380 & 6.6804 & 3.0531 & 0.00 & 11.00 \\
\hline
\end{tabular}




\section{APPENDIX 4: PREDICTIONS OF CHANGES IN PROBABILITIES OF TAX CUTS AND TAX INCREASES FROM THE MULTINOMIAL LOGIT ESTIMATES}

Consider the following simplified version of the multinomial logit model:

Suppose $p_{1}, p_{2}$, and $p_{3}$ denote the probabilities of tax rate cuts, no tax rate change, and tax rate increases, respectively. Our multinomial logit model that takes the state of no tax rate change as a reference category is simply specified as:

$$
\begin{aligned}
& \ln \left(\frac{p_{1}}{p_{2}}\right)=\beta_{0}+\beta_{1} x_{1}+\beta_{2} x_{2}+\ldots+e_{1} \\
& \ln \left(\frac{p_{3}}{p_{2}}\right)=b_{0}+b_{1} x_{1}+b_{2} x_{2}+\ldots+e_{3}
\end{aligned}
$$

The coefficients from the above equations, $\beta$ 's and $b$ 's, are respectively the log-odds ratio estimates of tax rate cuts and increases. We report such results in Tables 3-5.

A change in an exogenous variable, $x_{1}$, has the following effect on the $p_{1} / p_{2}$ and $p_{3} / p_{2}$ ratios:

$$
\begin{aligned}
& \Delta \ln \left(\frac{p_{1}}{p_{2}}\right)=\beta_{1} \Delta x_{1} \\
& \Delta \ln \left(\frac{p_{3}}{p_{2}}\right)=b_{1} \Delta x_{1} ; \text { or } \\
& \frac{\Delta\left(\frac{p_{1}}{p_{2}}\right)}{\frac{p_{1}}{p_{2}}}=\beta_{1} \Delta x_{1} \\
& \frac{\Delta\left(\frac{p_{3}}{p_{2}}\right)}{\frac{p_{3}}{p_{2}}}=b_{1} \Delta x_{1}
\end{aligned}
$$

Therefore we can solve for the $\Delta p s$ from the following three equations, given $p_{1}, p_{2}, p_{3}, b_{1}$, and $\beta_{1}$ :

$$
\begin{aligned}
& \frac{\Delta p_{1}}{p_{2}}-\frac{p_{1}}{p_{2}^{2}} \Delta p_{2}=\frac{p_{1}}{p_{2}} \beta_{1} \Delta x_{1} \\
& \frac{\Delta p_{3}}{p_{2}}-\frac{p_{3}}{p_{2}^{2}} \Delta p_{2}=\frac{p_{3}}{p_{2}} b_{1} \Delta x_{1} \\
& \Delta p_{1}+\Delta p_{2}+\Delta p_{3}=0
\end{aligned}
$$

This system yields the following equations:

$$
\begin{aligned}
& \Delta p_{1}=p_{1}\left[\beta_{1}\left(1-p_{1}\right)-p_{3} b_{1}\right] \Delta x_{1} \\
& \Delta p_{3}=p_{3}\left[b_{1}\left(1-p_{3}\right)-p_{1} \beta_{1}\right] \Delta x_{1}
\end{aligned}
$$

In computing the changes in the probabilities we have only used the coefficient estimates that are significant at the five per cent level. 


\section{About the Authors}

Bev Dahlby and Ergete Ferede are currently engaged in a number of studies of the provincial governments' tax and expenditure policies and responses to intergovernmental grants.

Bev Dahlby, Professor of Economics and Distinguished Fellow at The School of Public Policy, University of Calgary, attended St. Peter's College, the University of Saskatchewan, Queen's University and the London School of Economics. Dr. Dahlby has published extensively on tax policy and fiscal federalism.

He has served as a policy advisor to the federal and provincial governments. His international experience includes advisory work on tax reform for the IMF in Malawi, for the Thailand Development Research Institute, and for the World Bank in Brazil. He was a member of the Jenkins Panel on federal support to research and development, a research fellow at the C.D. Howe Institute, and currently serves as a member of Statistics Canada's advisory council.

Ergete Ferede is currently an associate professor of Economics at Grant MacEwan University and Fellow of the Institute of Public Economics, University of Alberta. His BA and MSc are from Addis Ababa University in Ethiopia and his PhD is from the University of Alberta in 2005. His main research areas are public finance and economic growth. His research has been published in National Tax Journal, International Tax and Public Finance, Small Business Economics, etc. He has previously taught a wide range of courses at Addis Ababa University, University of Alberta, and University of Windsor. He was a winner of the University of Windsor Teaching Score Award for the academic year 2005/6.

Abenezer Adjeic received his MA in Economics from the University of Alberta. He has also served as a teaching and research assistant in the Department of Economics at the University of Alberta. 


\title{
ABOUT THE SCHOOL OF PUBLIC POLICY
}

The School of Public Policy will become the flagship school of its kind in Canada by providing a practical, global and focused perspective on public policy analysis and practice in areas of energy and environmental policy, international policy and economic and social policy that is unique in Canada.

The mission of The School of Public Policy is to strengthen Canada's public service, institutions and economic performance for the betterment of our families, communities and country. We do this by:

- Building capacity in Government through the formal training of public servants in degree and nondegree programs, giving the people charged with making public policy work for Canada the hands-on expertise to represent our vital interests both here and abroad;

- Improving Public Policy Discourse outside Government through executive and strategic assessment programs, building a stronger understanding of what makes public policy work for those outside of the public sector and helps everyday Canadians make informed decisions on the politics that will shape their futures;

- Providing a Global Perspective on Public Policy Research through international collaborations, education, and community outreach programs, bringing global best practices to bear on Canadian public policy, resulting in decisions that benefit all people for the long term, not a few people for the short term.

\author{
The School of Public Policy \\ University of Calgary, Downtown Campus \\ 906 8th Avenue S.W., 5th Floor \\ Calgary, Alberta T2P $1 \mathrm{H} 9$ \\ Phone: 4032107100
}

\section{DISTRIBUTION}

Our publications are available online at www.policyschool.ca.

\section{DISCLAIMER}

The opinions expressed in these publications are the authors' alone and therefore do not necessarily reflect the opinions of the supporters, staff, or boards of The School of Public Policy.

\section{COPYRIGHT}

Copyright (C) 2013 by The School of Public Policy.

All rights reserved. No part of this publication may be reproduced in any manner whatsoever without written permission except in the case of brief passages quoted in critical articles and reviews.

\section{DATE OF ISSUE}

November 2013

\section{MEDIA INQUIRIES AND INFORMATION}

For media inquiries, please contact Morten Paulsen at 403-453-0062.

Our web site, www.policyschool.ca, contains more information about The School's events, publications, and staff.

\section{DEVELOPMENT}

For information about contributing to The School of Public Policy, please contact Courtney Murphy by telephone at 403-210-7201 or by e-mail at cdmurphy@ucalgary.ca.

\section{ISSN}




\section{RECENT PUBLICATIONS BY THE SCHOOL OF PUBLIC POLICY}

\section{ENHANCING THE ALBERTA TAX ADVANTAGE WITH A HARMONIZED SALES TAX}

http:/ / policyschool.ucalgary.ca/ ?q=content/ enhancing-alberta-tax-advantage-harmonized-sales-tax

Philip Bazel and Jack M. Mintz | September 2013

\section{ACCOUNTABILITY BY DESIGN: MOVING PRIMARY CARE REFORM AHEAD IN ALBERTA}

http:/ / policyschool.ucalgary.ca/ ?q=content/accountability-design-moving-primary-care-reform-ahead-alberta Dr. Shannon M. Spenceley, Cheryl Andres, Janet Lapins, Dr. Robert Wedel, Dr. Tobias Gelber, L.M. Halma | September 2013

\section{WIRELESS COMPETITION IN CANADA: AN ASSESSMENT}

http:/ / policyschool.ucalgary.ca/?q=content/ wireless-competition-canada-assessment Jeffrey Church and Andrew Wilkins | September 2013

THE CANADIAN MANUFACTURING SECTOR, 2002-2008: WHY IS IT CALLED DUTCH DISEASE?

http:/ / policyschool.ucalgary.ca/?q=content/ canadian-manufacturing-sector-2002-2008-why-it-called-dutchdisease

Stephen Gordon | September 2013

REDISTRIBUTION OF INCOME: POLICY DIRECTIONS

http:/ / policyschool.ucalgary.ca/?q=content/redistribution-income-policy-directions James Davies | August 2013

INCOME INEQUALITY AND INCOME TAXATION IN CANADA: TRENDS IN THE CENSUS 1980-2005 http:/ / policyschool.ucalgary.ca/ ?q=content/income-inequality-and-income-taxation-canada-trends-census1980-2005

Kevin Milligan | August 2013

INCOME INEQUALITY, REDISTRIBUTION AND ECONOMIC GROWTH http:/ / policyschool.ucalgary.ca/?q=content/income-inequality-redistribution-and-economic-growth Bev Dahlby and Ergete Ferede | August 2013

DIPLOMACY, GLOBALIZATION AND HETEROPOLARITY: THE CHALLENGE OF ADAPTATION http:/ / policyschool.ucalgary.ca/?q=content/ diplomacy-globalization-and-heteropolarity-challenge-adaptation Daryl Copeland | August 2013

UNHEALTHY PRESSURE: HOW PHYSICIAN PAY DEMANDS PUT THE SQUEEZE ON PROVINCIAL HEALTH-CARE BUDGETS

http:/ / policyschool.ucalgary.ca/?q=content/ unhealthy-pressure-how-physician-pay-demands-put-squeezeprovincial-health-care-budgets

Hugh M. Grant and Jeremiah Hurley | July 2013

TRENDS, PEAKS, AND TROUGHS: NATIONAL AND REGIONAL EMPLOYMENT CYCLES IN CANADA http:/ / policyschool.ucalgary.ca/?q=content/trends-peaks-and-troughs-national-and-regional-employmentcycles-canada

Ronald Kneebone and Margarita Gres | July 2013 